Wayne State University

DigitalCommons@WayneState

Wayne State University Theses

$1-1-2010$

\title{
The Role Of Mitochondria In The Radiation- Induced Bystander Effect In Human Lymphoblastoid Cells
}

Sountharia Rajendran

Wayne State University,

Follow this and additional works at: http://digitalcommons.wayne.edu/oa_theses

\section{Recommended Citation}

Rajendran, Sountharia, "The Role Of Mitochondria In The Radiation-Induced Bystander Effect In Human Lymphoblastoid Cells" (2010). Wayne State University Theses. Paper 26. 
THE ROLE OF MITOCHONDRIA IN THE RADIATION-INDUCED BYSTANDER EFFECT IN HUMAN LYMPHOBLASTOID CELLS

by

\section{SOUNTHARIA RAJENDRAN}

THESIS

Submitted to the Graduate School

of Wayne State University,

Detroit, Michigan

in partial fulfillment of the requirements

for the degree of

MASTER OF SCIENCE

2010

MAJOR: BIOLOGICAL SCIENCES

Approved by:

Advisor

Date 


\section{DEDICATION}

I would like to dedicate this work to my grandparents, parents and all my family members. They have been my greatest strength, and this work would not have been possible without their unconditional love and support. 


\section{ACKNOWLEDGMENTS}

I would like to take this opportunity to thank everyone who has been a part of this successful journey.

First, I would like to thank my advisor, Dr. James D. Tucker for his encouragement and support without which this thesis wouldn't have taken its shape. My gratitude is due to him for his insightful comments and useful suggestions towards my thesis. Without his guidance and persistent help this research would not have been possible.

My acknowledgements are due to my committee members, Dr. Athar Ansari and Dr. Karen Beningo.

I would like to extend my gratitude to Dr. Robert A. Thomas for his guidance, support and encouragement that helped me to complete this research successfully. I sincerely thank Dr. Scott Harrison for his time and expertise with the statistical analyses. I thank Dr. Gilda Gali Hillman and her lab members, at the Gershenson Radiation Oncology Center, for their help in radiating the samples.

I whole-heartedly thank my past and present lab members for their help and valuable insights. I also thank them for making the laboratory a comfortable place to work in. I would especially like to acknowledge Dr. Raj Asur for her help in teaching me the techniques required for this study. My special thanks to my friend, Ramya Malarini Loganathan for her immense help, moral support and valuable discussions.

My deepest gratitude goes to my family for their boundless love and support throughout my life; this thesis is simply impossible without them. I am deeply indebted to my mom for her love, patience, trust and constant support towards me. 


\section{TABLE OF CONTENTS}

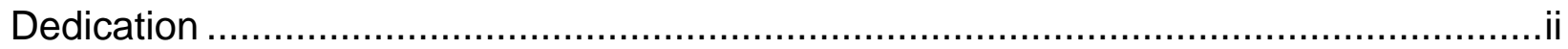

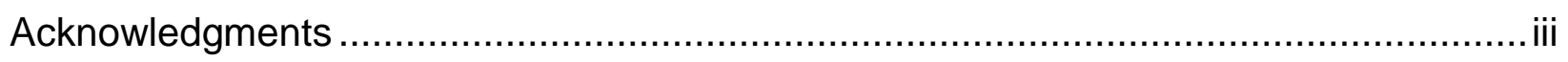

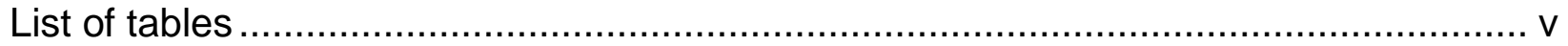

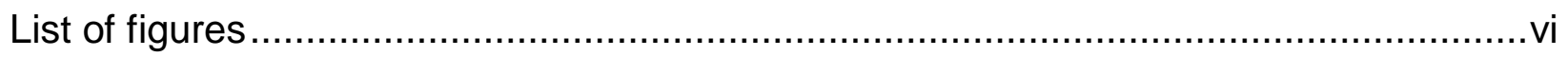

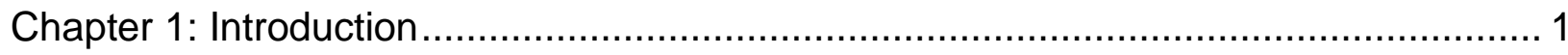

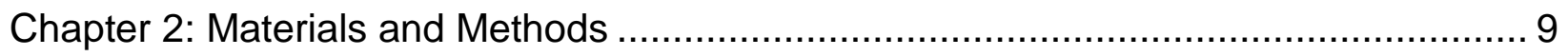

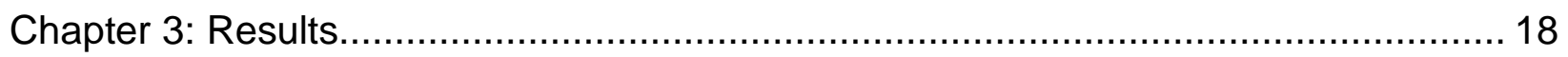

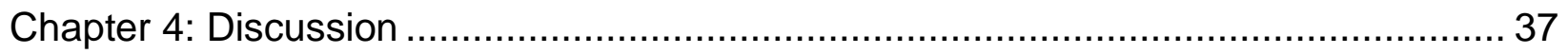

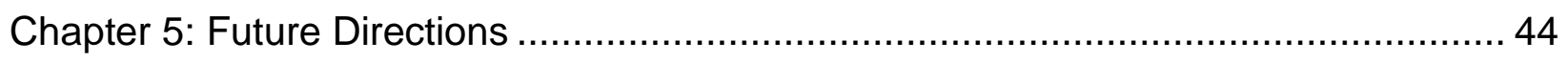

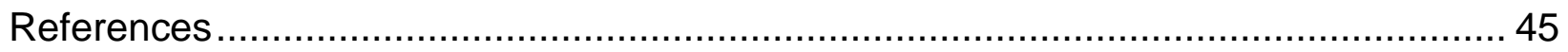

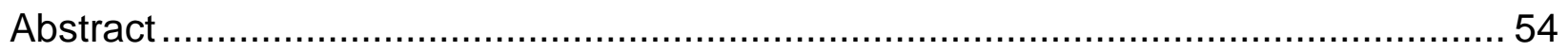

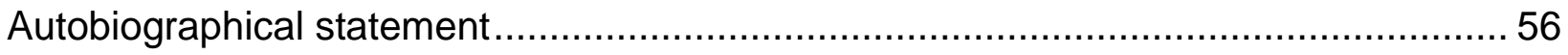




\section{LIST OF TABLES}

Table 1: Comparisons of micronucleus dose responses in normal and mitochondrial mutant cell lines................................................................................ 19

Table 2: Post hoc comparisons of the six cell lines ...................................................... 20

Table 3: Post hoc comparisons of the micronucleus frequencies at each radiation

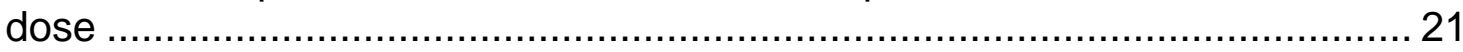

Table 4: Summary of results for the bystander effects evaluated in normal and mitochondrial mutant cell lines

Table 5: Concentration range-finding experiment for rotenone and oligomycin ............ 30

Table 6: ANOVA results for inhibition of the bystander effect in normal cell lines at times $\mathrm{T} 1, \mathrm{~T} 2, \mathrm{~T} 3$ and $\mathrm{T} 4$

Table 7: Post hoc comparisons of the different treatment types at times T1, T2, T3, and $\mathrm{T} 4$

Table 8: Post hoc comparisons of the treatment times T1, T2, T3, and T4 36 


\section{LIST OF FIGURES}

Figure 1: Images of binucleated cells with and without micronuclei stained with acridine orange and observed under $1000 \mathrm{X}$ total magnification using an epifluorescence microscope.

Figure 2: Experimental design for the study on inhibition of the bystander effect at different times following exposure

Figure 3: Micronucleus frequencies in normal and mitochondrial mutant cells directly exposed to $\mathrm{X}$-irradiation

Figure 4: Micronucleus frequencies in normal and mitochondrial mutant cells grown in conditioned media obtained from the same cell line following irradiation ... 23

Figure 5: Micronucleus frequencies in normal and mitochondrial mutant cells grown in conditioned media obtained from other normal or mitochondrial cell lines following irradiation.

Figure 6: Bystander effects observed in normal and mitochondrial mutant cell lines .... 28

Figure 7: Micronucleus frequencies in normal cells treated with mitochondrial inhibitors during the entire culture period

Figure 8: Micronucleus frequencies in normal cells treated with mitochondrial inhibitors at times T1, T2, T3 and T4. 


\section{CHAPTER 1: Introduction}

The bystander effect

Every individual is constantly exposed to radiation either from natural sources such as cosmic rays and radioactivity in the ground, or from radiation used in therapeutic and diagnostic purposes. Radiation induced damage is not limited to the cells directly exposed to radiation but also includes bystander cells. The bystander effect is a phenomenon by which unexposed cells show cellular responses similar to nearby, directly exposed, cells. For ionizing radiation, cells that are directly irradiated and the surrounding bystander cells that are not directly irradiated both show a response to radiation by activating existing signaling pathways (Maguire et al., 2005, Mothersill \& Seymour, 2003). The bystander effect was recently shown to be caused by chemicals such as the DNA cross-linker agent mitomycin $\mathrm{C}$ and the radiomimetic compound phleomycin in addition to ionizing radiation (Asur et al., 2009b). Cells directly exposed to ionizing radiation or chemicals, and those exposed to media from treated cells, show involvement of MAPK pathways (Asur et al., 2009a, Dent et al., 2003). The other stress factors that lead to bystander responses include ultraviolet light (Banerjee et al., 2005) and photodynamic stress (Chakraborty et al., 2009).

The bystander phenomenon has been of interest for many years. In 1954, children receiving radiation to the spleen for chronic granulocytic leukemia showed damage to the bone marrow in the sternum (Parsons et al., 1954). The plasma from patients subjected to therapeutic X-rays led to chromosomal damage in lymphocytes held in short term cultures (Hollowell \& Littlefield, 1968). Non-pelvic irradiation administered to mothers up to 8 months before becoming pregnant resulted in unstable 
chromosome aberrations in lymphocytes of human babies and baby rabbits (GoyanesVillaescusa, 1971).

As a result of radiation exposure, soluble transmissible clastogenic factors are either secreted or excreted by cellular elements and these may affect nearby unirradiated cells (Faguet et al., 1984). A long-lived gap junction-mediated bystander effect is observed in human diploid fibroblasts and TP53 is found to be involved in signal transduction (Azzam et al., 1998, Azzam et al., 2000). Thus the bystander effect is mediated by both soluble transmissible factors that are secreted by irradiated cells and by gap junction-mediated intercellular communication. The clastogenic bystander factors may persist for several years (Pant \& Kamada, 1977). At least some of these factors have a low molecular weight and their production involves lipid peroxidation and oxidative stress pathways (Emerit, 1994). The bystander factors are heat-labile but are stable when frozen and do not require cell-to-cell contact to induce their effects in recipient cells (Mothersill \& Seymour, 1998).

The bystander effect involves two distinct processes, namely the production of bystander signals and the response to those signals (Mothersill et al., 2000, Mothersill et al., 2001). The response to bystander signals is dependent on the phenotype of the unexposed cells and the magnitude of the bystander effect is dependent on the irradiated cells (Vines et al., 2008). The DNA repair phenotype of the cells responding to bystander signals plays an important role in the overall response (Kashino et al., 2004, Kashino et al., 2007). These findings suggest that the generation of bystander signals and the response to these signals are two individual processes and are cell line dependent (Mothersill et al., 2000). 
Importance of the bystander effect

The bystander effect may be of practical importance in two major fields of radiation science, namely risk assessment and radiotherapy (Mothersill \& Seymour, 2001). In vivo non-targeted effects are serious problems implicated in radiation-induced carcinogenesis (Sugahara \& Watanabe, 1994). Organs or individuals exposed to low doses of radiation, either due to environmental exposure or to radiation from therapy or diagnostic tests, are at risk of bystander effects. The existence of radiation-induced bystander effects means that we do not fully understand the association between the number of cells exposed to radiation and the number of cells that are actually at risk and show the effects of damage, such as point mutations, chromosome aberrations or apoptosis. Bystander cells are at risk of delayed effects of damage such as genomic instability, a feature usually associated with cancer (Mothersill \& Seymour, 2001). Thus, not only the directly irradiated cells but also the unexposed bystander cells are at risk for radiation damage. The assessment of the radiation-induced effects should, therefore, take into account both the direct and the bystander effects. Such a change in risk assessment would facilitate the integration of protection against environmental exposures with radiation treatment, and will help develop new strategies for protecting the public from exposure to cancer-causing agents (Mothersill \& Seymour, 2004). Mitochondria and mitochondrial diseases

Mitochondria produce ATP as the energy source for cells. ATP is produced by the oxidative phosphorylation that occurs in the mitochondrial inner membrane. Mitochondria are prokaryotic in origin (Andersson et al., 2003) and have their own genome with a modified genetic code. The similarities between bacterial respiration and 
mitochondrial functions, together with phylogenetic studies based on mitochondrial proteins, suggest that mitochondria are derived from an ancestral endosymbiont (Andersson et al., 2003, Cavalier-Smith, 2006). The mammalian mitochondrial genome is a double stranded, covalently closed circular molecule that is composed almost entirely of coding regions. It has some overlapping genes that increase the potential of point mutations or deletions to have dramatic phenotypic effects (Bykhovskaya et al., 2004, Rufa et al., 2005). The mitochondrial DNA (mtDNA) is located close to the inner mitochondrial membrane (Fiskum et al., 1999) and is therefore expected to be highly susceptible to reactive oxygen species that cause mutations. The lack of a histone coat on the mtDNA and the limited proofreading ability of the mitochondrial DNA polymerase make mtDNA more susceptible to damage compared to nuclear DNA (Alexeyev et al., 2004).

There are tens to hundreds of mitochondria in most mammalian cells, each containing approximately two to ten copies of the mitochondrial genome (Morel et al., 1999). The human mitochondrial genome has two rRNA genes, twenty two tRNA genes, and thirteen protein-coding genes that form subunits of the enzyme complexes that are involved in the oxidative phosphorylation (OXPHOS) pathway. Both nuclear and mitochondrial gene products are involved in the OXPHOS pathway and thus mutations in either of them will affect the electron transport and ATP synthesis (DeHaan et al., 2004) that might result in tissue dysfunctions and lead to diseases (Sun et al., 1998).

Leber's hereditary optic neuropathy, also known as Leber's optic atrophy, and Leigh's syndrome are two such mitochondrial diseases caused by mutations in the mitochondrial DNA. Leber's optic atrophy leads to degeneration of retinal ganglion cells. 
This predominantly affects young adult males and results in acute or subacute loss of central vision. These are caused by missense mutations in the genes for the subunits of the electron transport chain complexes I, III and IV (Brown et al., 1992). A guanine to adenine transition at bp 11778 of the NADH dehydrogenase 4 (ND4) subunit of mitochondrial complex I leads to a marked decrease in the rates of ATP production or respiration (Majander et al., 1996).

Leigh's disease is a rare inherited neurometabolic disorder that affects the central nervous system. This progressive condition first appears in infants between the ages of three months and two years. Rarely, it occurs in teenagers and adults. This disease can be caused by mutations in both nuclear and mitochondrial-encoded genes involved in energy metabolism or by deficiencies of the enzyme pyruvate dehydrogenase. Severe deficiency in mitochondrial ATP synthesis is found in people with this disorder (Dahl, 1998). The symptoms include loss of appetite, vomiting, irritability, seizures, generalized weakness, lack of muscle tone, and episodes of lactic acidosis, which can lead to impairment of respiratory and kidney function.

Mitochondria and bystander effects

Although the bystander effect has been of interest for many years, the molecular mechanisms underlying it are not clear. Intact mitochondrial DNA is required to produce a bystander signal, as cells lacking mitochondrial DNA did not produce bystander signals although they could respond to signals from normal cells with intact mitochondrial DNA (Tartier et al., 2007). Loss of cytochrome c impairs cells' response to bystander signals (Yang et al., 2009). ATP is required for most energy-dependent processes, including repair, repopulation, and programmed cell death (Elmore, 2007, 
Mothersill et al., 2000, Cahill et al., 2006). As the bystander effect is both energy dependent and involves the role of intact mitochondria, cell lines with mutations in mitochondrial genes responsible for ATP synthesis are hypothesized to show a decreased bystander effect when compared to normal cell lines. The current study aims at identifying the role of mitochondria in the radiation-induced bystander effect.

\section{Present study}

The long term goal of this study is to determine the role of mitochondria in the radiation-induced bystander effect and thus, elucidate the molecular mechanism that underlies the bystander effect. The key questions that are addressed in this study are: 1) Do cell lines harboring mutations in the mitochondrial genes responsible for ATP synthesis show a decreased bystander effect? 2) Do these mitochondrial mutant cell lines generate and respond to bystander signals? 3) Do normal cell lines behave similar to the mitochondrial mutant cell lines when their mitochondrial ATP synthesis is inhibited?

To address the first question, we determined whether there is a decrease in the bystander effect in cell lines that have mutations in the mitochondrial genes involved in ATP synthesis using the cytokinesis-block micronucleus assay which detects chromosomal damage caused by genotoxic agents. Evaluation of micronuclei is one of the most reliable cytogenetic assays and has been used for many years to quantify DNA damage (Fenech \& Morley, 1985). A quantitative analysis of the bystander effect was performed using this assay in both the normal and mitochondrial mutant cell lines.

The cell lines used in this study do not have gap junctions and thus, any bystander effect that is seen must be due to the factors secreted into the media. The 
normal cell lines exhibit the bystander effect and were used as controls. The mitochondrial mutant cell lines harbor mutations that lead to diseases including Leber's optic atrophy and Leigh's syndrome. People with these diseases show decreased rates of ATP synthesis. The quantitative analysis of the bystander effect indicates that cell lines harboring mutations in the mitochondrial genes responsible for ATP synthesis do not show a bystander effect when compared to normal cell lines. Thus, the ATP synthesized by mitochondria might play an important role in the bystander effect.

The bystander effect is composed of two processes: generation of the bystander signals, and response to those signals (Vines et al., 2008, Mothersill et al., 2000). This led to the second question, which asks whether the absence of the bystander effect in mitochondrial mutant cells is due to the lack of generation of bystander signals or to the absence of response to these signals, or both. To investigate this issue, a matrix-style experiment was performed with the normal and mitochondrial mutant cell lines using the micronucleus assay. The rationale behind this experiment is that the normal cells generate and respond to bystander signals. Thus, a lack of a bystander effect in this experiment will help determine whether the mutant cells fail to generate and/or fail to respond to the bystander signals. The results indicate that the mitochondrial mutant cells neither generate nor respond to the bystander signals. Thus, the mitochondrial ATP synthesis might be important for both the generation and response to bystander signals.

The third question addresses whether the normal cells show a decreased bystander effect when their mitochondrial ATP synthesis is inhibited. The radiationinduced bystander effect was analyzed in cells treated with the mitochondrial inhibitors 
rotenone and oligomycin. The results indicate that normal cells do not exhibit the bystander effect when their mitochondrial ATP synthesis is inhibited. Following this experiment, the time period during which the inhibition was effective was determined by adding and removing the inhibitors at selected time points. The bystander effect was found to be inhibited when rotenone or oligomycin were added 24 hours before radiation, then removed immediately after radiation. Similarly, inhibition was observed when rotenone or oligomycin were added immediately following radiation, or after exposing the cells to conditioned media from the same cell line following radiation. However, when rotenone or oligomycin were added just prior to radiation and were removed immediately after exposure, the bystander effect was not inhibited, perhaps because the length of inhibition was shorter than for the other time points. 


\section{CHAPTER 2: Materials and Methods}

$\underline{\text { Cell lines }}$

Normal human lymphoblastoid cell lines (GM15036, GM15510) and cell lines with mitochondrial mutations (GM10744, GM10742, GM13740, and GM13741) were obtained from the Coriell Cell Repository. Cell lines GM10742 and GM10744 have an $11778 \mathrm{G}>\mathrm{A}$ mutation in the NADH dehydrogenase subunit 4 (MTND4) gene that leads to Leber's optic atrophy. GM13740 and GM13741 cells have an 8993 T>G mutation in the ATPase 6 (MTATP6) gene that causes Leigh's syndrome. The normal lymphoblastoid cell lines were used as positive controls because they are known to exhibit a bystander effect.

$\underline{\text { Cell culture }}$

Cell culture was performed according to the protocol suggested by Coriell. The cell lines were grown in T-25 culture flasks (Corning, NY and ISC BioExpress, Kaysville, UT) containing $10 \mathrm{ml}$ of RPMl1640 medium (GIBCO, Grand Island, NY and Hyclone, Logan, Utah) supplemented with 15\% Fetal Bovine Serum (FBS, Atlanta Biologicals, Lawrenceville, GA), 2 mM L-glutamine (GIBCO, Grand Island, NY), penicillinstreptomycin (100 units/ml penicillin G Sodium, $100 \mu \mathrm{g} / \mathrm{ml}$ Streptomycin sulfate in $0.85 \%$ saline) (GIBCO, Grand Island, NY) and fungizone (amphotericin B, $2.5 \mu \mathrm{g} / \mathrm{ml}, 0.2 \mu \mathrm{m}$ filtered) (Hyclone, Logan, Utah). Cultures were maintained at $37^{\circ} \mathrm{C}$ in a fully humidified $5 \% \mathrm{CO}_{2}$ incubator. The cells were passaged every 72 hours or when the cell density reached $10^{6}$ cells $/ \mathrm{ml}$. 
$\underline{\text { Irradiation }}$

The cell lines in T-25 culture flasks containing $10 \mathrm{ml}$ of culture media were $\mathrm{X}$ irradiated with 0 Gy (control), 1 Gy and 2 Gy. The irradiations were performed at a dose rate of $88 \mathrm{cGy} / \mathrm{min}$ by using a Pantak X-ray generator operated at $320 \mathrm{kVp}$, at the Gershenson Radiation Oncology Center, Detroit, Michigan. The culture flasks were returned to the incubator immediately after irradiation.

\section{Direct exposure}

Four hours after irradiation, $6 \mu \mathrm{g} / \mathrm{ml}$ of Cytochalasin B (Sigma, St. Louis, MO) dissolved in DMSO (Fisher Scientific, Pittsburgh, PA) was added to the cell lines that were directly irradiated. The final concentration of DMSO in culture media was $1.1 \%$. The cell cultures were incubated at $3^{\circ} \mathrm{C}$ for 28 hours.

\section{$\underline{\text { Media transfer }}$}

Four hours after irradiation, the cell cultures from the unirradiated and irradiated flasks were transferred to $15 \mathrm{ml}$ centrifuge tubes (Nalgene Nunc International, Rochester, NY), and centrifuged at $1400 \mathrm{rpm}$ for 5 minutes. The media from the unirradiated cell lines was removed by aspiration. The media from the irradiated cell lines was pipeted without disturbing the cell pellet and was transferred to the cells from the unirradiated flasks. The media from the irradiated cell lines was considered to be "conditioned" as this contained the factors secreted by the irradiated cells. The unirradiated cells in the conditioned media were transferred to T-25 culture flasks and 6 $\mu \mathrm{g} / \mathrm{ml}$ of Cytochalasin B was added to inhibit cytokinesis. The cell cultures were then incubated at $37^{\circ} \mathrm{C}$ for 28 hours as described. 


\section{Micronucleus assay}

After 28 hours, the cells that had been directly exposed to radiation and cells exposed to conditioned media were transferred to $15 \mathrm{ml}$ centrifuge tubes and centrifuged at $1400 \mathrm{rpm}$ for 5 minutes. The cell pellets were resuspended in $1 \mathrm{X}$ phosphate buffered saline (PBS) (Fisher Scientific, Pittsburgh, PA) and were centrifuged onto clean microscope slides, using a cytocentrifuge (Statspin, Westwood, MA), for 4 minutes at $1300 \mathrm{rpm}$. The slides were air dried and then fixed in $100 \%$ methanol (Fisher Scientific, Pittsburgh, PA) for 15 minutes. The cells were stained with $100 \mu \mathrm{l}$ of acridine orange $(0.5 \mathrm{mg} / \mathrm{ml}$ in $1 \mathrm{X}$ PBS) (Allied Chemical Corporation, Morristown, NJ). The dye was spread uniformly over the cells and the slides were left in a box covered with aluminum foil for 1 minute. The excess stain was removed by washing once in 1X PBS and twice in distilled water for 3 minutes each. The cytokinesis-blocked binucleated cells were scored for micronuclei using an epifluorescence microscope (Nikon Eclipse 80i). The slides were coded prior to scoring to prevent scorer bias. The micronuclei were identified based on established criteria. The numbers of micronuclei in binucleated cells with both the nuclei distinctly separate from each other were found. Micronuclei are oval or round in shape with smooth edges and are in the same color as the main nuclei but are smaller in size. The micronuclei should be located in the cytoplasm and be distinctly separate from the main nuclei. The number of micronuclei can range from 0 to $>10$. One thousand binucleated cells were scored for each treatment condition by a single trained observer. Images of binucleated cells with and without micronuclei are shown in Figure 1. 

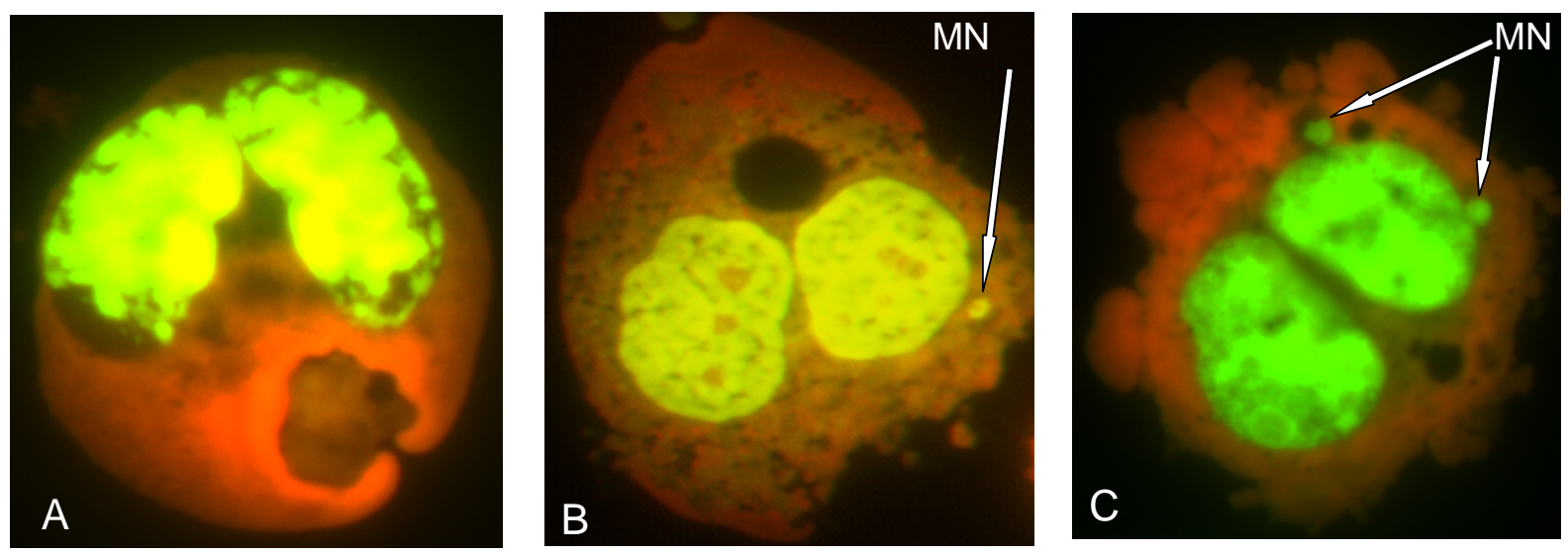

Figure 1. Images of binucleated cells with and without micronuclei stained with acridine orange and observed under 1000X total magnification using an epifluorescence microscope. Normal binucleated cell $(\mathbf{A})$, binucleated cell with a single micronucleus $(\mathbf{B})$ and binucleated cell with two micronuclei (C). MN: Micronucleus.

\section{Mitochondrial inhibitors}

The mitochondrial mutant cell lines used in this study harbor mutations in respiratory chain complexes I and V. The normal human lymphoblastoid cell lines (GM15036, GM15510) were treated with rotenone (Sigma, St. Louis, MO) that inhibits mitochondrial NADH dehydrogenase complex I, or with oligomycin (Calbiochem, San Diego, CA) that inhibits ATPase complex V.

\section{$\underline{\text { Rationale behind the selection of inhibitor concentrations }}$}

The concentrations of rotenone and oligomycin that were used to inhibit the bystander effect in normal cell lines were selected based on experiments performed to determine the Nuclear Division Index (NDI) (Eastmond \& Tucker, 1989) of treated cell lines. NDI is the average number of nuclei per cell. NDI is important for the micronucleus assay as the number of binucleated cells should be sufficient to enumerate micronuclei. Concentrations of rotenone ranging from $0.12 \mathrm{nM}$ to $5 \mu \mathrm{M}$ and of oligomycin ranging from $0.12 \mathrm{nM}$ to $10 \mu \mathrm{M}$ were added to the normal human 
lymphoblastoid cell lines, 24 hours after splitting the cells. Twenty eight hours later, media transfer was performed and $6 \mu \mathrm{g} / \mathrm{ml}$ of Cytochalasin B was added to each culture. After 28 hours from the time of media transfer, the cells were centrifuged onto microscope slides as described earlier and were stained with acridine orange, also as described earlier. The NDI was determined by scoring 100 cells for each treatment condition. Based on the NDI determined (data not shown), we found that normal cell lines treated with 1.5, 3, 6 and $10 \mathrm{nM}$ rotenone, and $0.75,1.5,3$ and $6 \mathrm{nM}$ oligomycin had enough binucleated cells to enumerate micronuclei.

$\underline{\text { Radiation- induced bystander effect and mitochondrial inhibitors }}$

Cell lines GM15510 and GM15036 were treated with the above selected concentrations of rotenone and oligomycin, 24 hours after splitting the cells. The stock solutions of 10,20 and $100 \mu \mathrm{M}$ rotenone, and 5, 10 and $20 \mu \mathrm{M}$ oligomycin were prepared in DMSO. The highest concentration of DMSO in cells treated with inhibitors was $0.03 \%$. Thus, cells treated with $0.03 \%$ of DMSO alone were used as solvent controls. The cells were exposed to 0 Gy (control) and 2 Gy X-radiation, 24 hours after adding the inhibitors. Irradiation and media transfer were performed as described earlier. After 28 hours from the time of media transfer, the cells were centrifuged onto microscope slides as described earlier and were stained with acridine orange, also as described earlier. NDI was determined for all these treatment conditions. $\underline{\text { Inhibition of bystander effect at different times }}$

Inhibition of the bystander effect in the normal cell lines was analyzed by blocking the generation or response to bystander signals or both. This was performed by adding and removing the mitochondrial complex inhibitors at various times along the course of 
the experiment. There were five different times, T-entire, T1, T2, T3 and T4, during which the inhibitors were added and removed from the cells. The experiments were performed as shown in Figure 2. During the wash step following radiation at times T1 and T2, the cultures with the inhibitors were transferred to $15 \mathrm{ml}$ centrifuge tubes and centrifuged at $1400 \mathrm{rpm}$ for 5 minutes. The media with the inhibitors was removed by aspiration and the cells were re-suspended in fresh media. At time T-entire, both the normal cell lines were treated with 1.5, 3, 6 and $10 \mathrm{nM}$ rotenone. GM15510 cells were treated with $0.75,1.5,3$ and $6 \mathrm{nM}$ oligomycin while the highest testable concentration of oligomycin in GM15036 cells was $3 \mathrm{nM}$. In the other four inhibition times, GM15510 cells were treated with $10 \mathrm{nM}$ rotenone or with either $3 \mathrm{nM}$ or $6 \mathrm{nM}$ oligomycin, while GM15036 cells were treated with $10 \mathrm{nM}$ rotenone or $3 \mathrm{nM}$ oligomycin. 


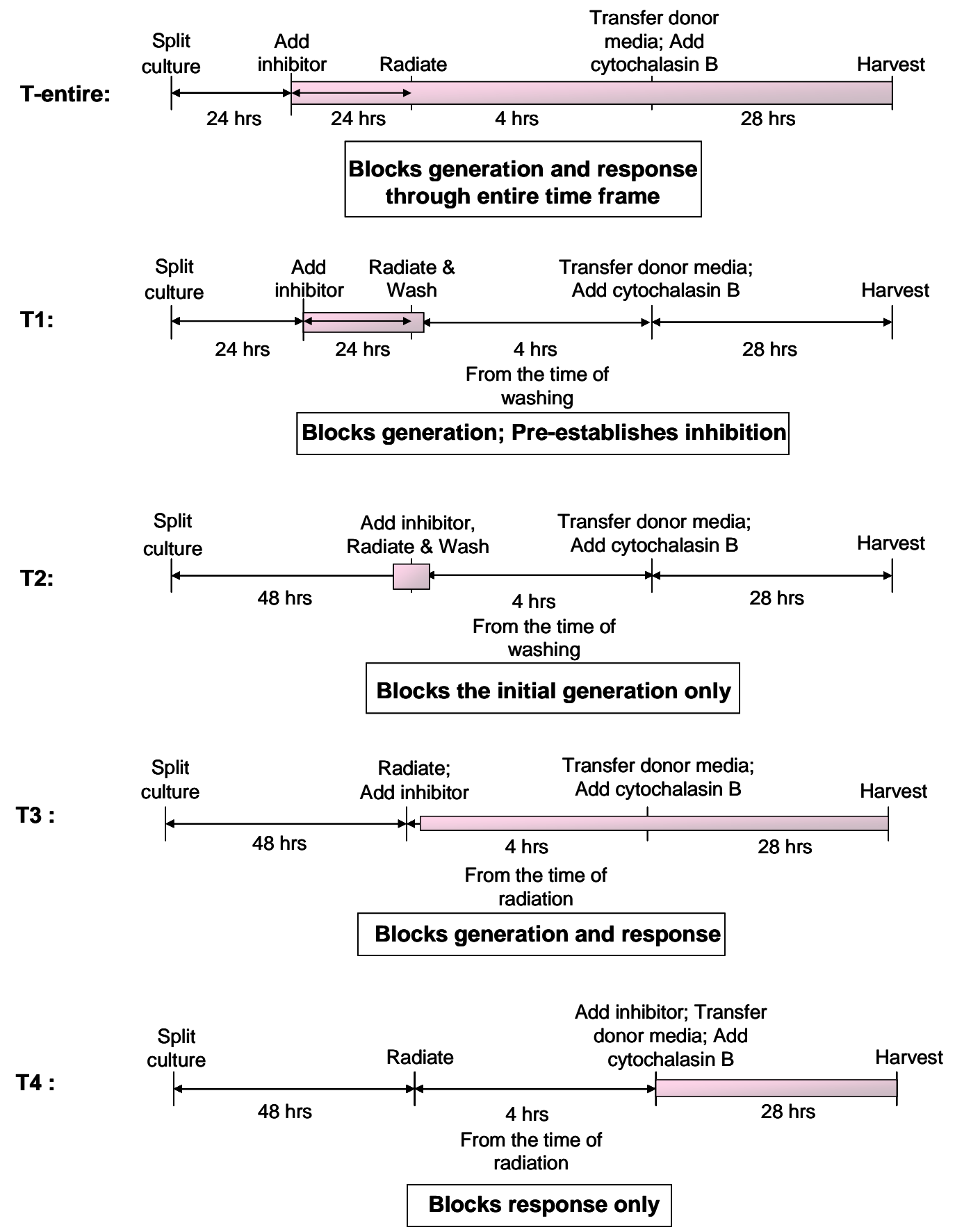

Figure 2. Experimental design for the study on inhibition of the bystander effect at different times following exposure. T-entire: Inhibitor was added 24 hours after splitting the cells and was present to the end of the experiment; T1: Inhibitor was added 24 hours after splitting the cells and was washed off immediately after radiation; T2: Inhibitor was added just prior to radiation and was washed off immediately after radiation; T3: Inhibitor was added just after radiation and was present to the end of the experiment; T4: Inhibitor was added just before the media transfer at 4 hours after radiation and was present to the end of the experiment. 


\section{Statistical Analyses}

A $t$-test was performed to determine the difference in dose response exhibited by the normal and mutant cell lines, considering the change in micronucleus frequencies and dose as the response variable and the ordinal factor, respectively. The analyses were performed using R 2.6.2. Analysis of variance (ANOVA) was also performed to evaluate the radiation-induced dose responses in the normal and mitochondrial mutant cells. The parameters evaluated were cell line (GM15510, GM15036, GM13740, GM13741, GM10742 and GM10744), radiation dose (0, 1, and 2 Gy) and the interaction between cell line and dose. The analyses were performed using PASW Statistics Version 18.0. Tukey HSD post hoc tests comparing the six different cell lines and the micronucleus frequencies obtained for all three radiation groups were then performed. The analyses were performed using PASW Statistics Version 18.0.

The Welch two sample $t$-test was used to evaluate differences in the bystander effect between normal cells, between normal and mutant cells, and between mutant cells. The micronucleus frequencies at $1 \mathrm{~Gy}$ and $2 \mathrm{~Gy}$, and the induced micronucleus frequencies (i.e. the irradiated value minus the unirradiated value) for 1 Gy and 2 Gy were compared. The analyses were performed using R 2.6.2.

The Welch two sample $t$-test was also used to determine the concentration of rotenone and oligomycin that led to an inhibition of bystander effect in GM15510 and GM15036 cells. The analysis was performed on the induced micronucleus frequencies (i.e. 2 Gy minus 0 Gy) by growth in conditioned media. The analyses were performed using $R$ 2.6.2. 
Analysis of variance (ANOVA) was performed to determine the significance of inhibition caused due to rotenone and oligomycin at different treatment times. The parameters evaluated were cell line (GM15510, GM15036), treatment type (DMSO, rotenone and oligomycin), treatment time (T1, T2, T3 and $\mathrm{T} 4)$, and all possible two-way and three-way interaction terms. The analyses were performed using PASW Statistics Version 18.0. Tukey HSD post hoc tests comparing the different treatment types and treatment times were then performed. The analyses were performed using PASW Statistics Version 18.0.

The $95 \%$ confidence intervals were estimated as described (Lilienfeld et al., 1967). 


\section{CHAPTER 3: Results}

$\underline{\text { Radiation induced dose responses in normal and mitochondrial mutant cells }}$

The number of micronuclei per 1000 binucleated cells that were directly exposed to ionizing radiation showed dose-responsive increases in the normal cell lines GM15510 and GM15036 (Figure 3A), and in the mitochondrial mutant cell lines GM13740, GM13741, GM10742, and GM10744 (Figure 3B).
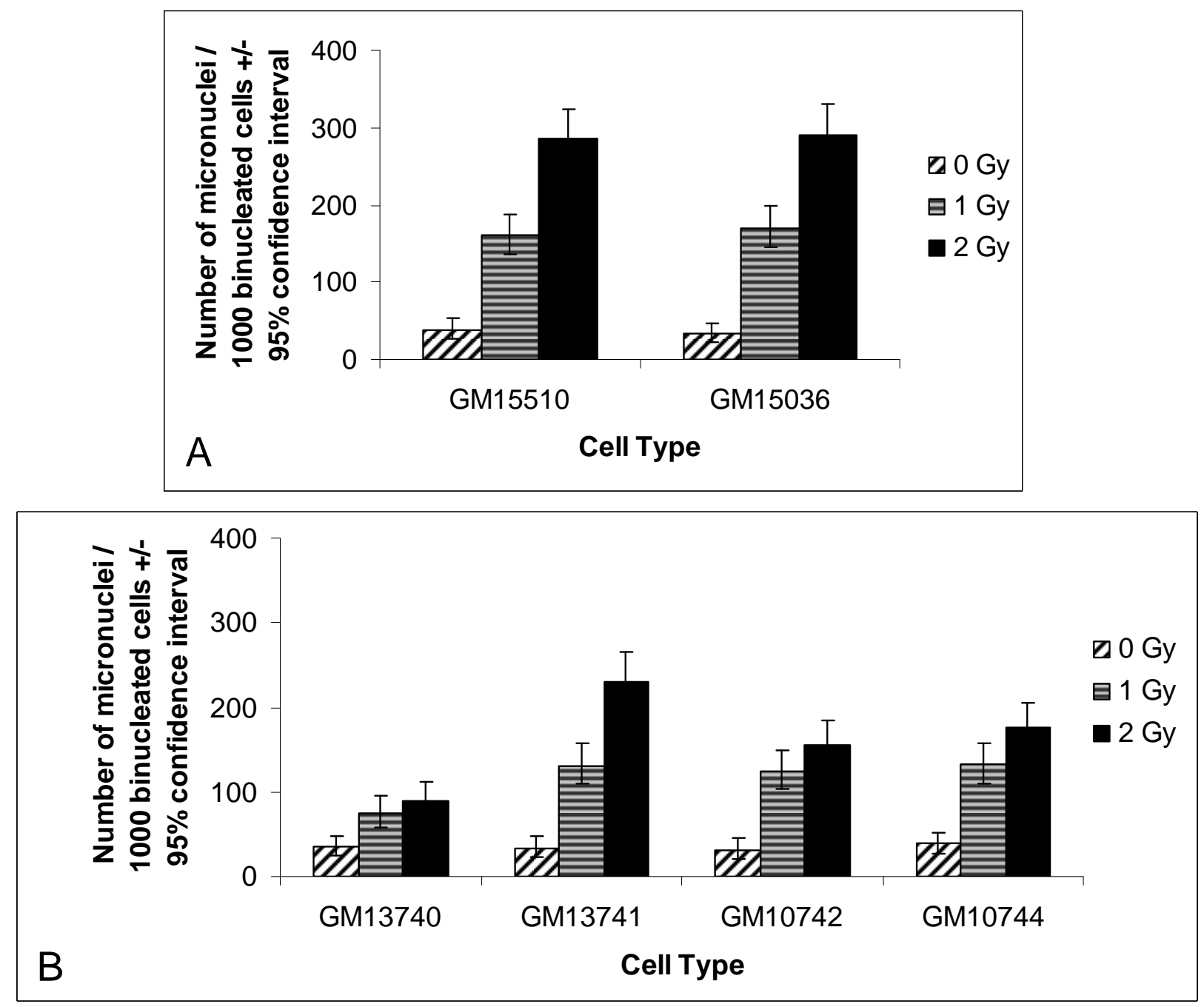

Figure 3. Micronucleus frequencies in normal and mitochondrial mutant cells directly exposed to $X$-irradiation. Normal cell lines $(\mathbf{A})$ and mitochondrial mutant cell lines (B). Vertical bars represent the $95 \%$ confidence intervals. 
In these experiments, the most meaningful response value is the change in micronucleus frequencies with radiation dose. A $t$-test was performed considering the change in micronucleus frequencies as the response variable and dose as the ordinal factor. The results, shown in Table 1, indicate that the normal cells differed significantly from the mitochondrial mutant cells based on the changes in micronucleus frequencies from 0 Gy to 1 Gy $(p=0.04), 0$ Gy to 2 Gy $(p=0.025)$ and 1 Gy to 2 Gy $(p=0.022)$. Thus, the normal cells show a significantly greater response to radiation than the mutant cells.

Table 1: Comparisons of micronucleus dose responses in normal and mitochondrial mutant cell lines.

\begin{tabular}{ccccc}
\hline & \multicolumn{3}{c}{ Changes in micronucleus frequencies } \\
\cline { 2 - 5 } \multicolumn{2}{c}{ Cell line } & 0 Gy to 1 Gy & 1 Gy to 2 Gy & 0 Gy to 2 Gy \\
\hline GM15510 & (normal) & 121 & 126 & 247 \\
GM15036 & (normal) & 136 & 122 & 258 \\
GM13740 & (Leigh's) & 40 & 15 & 55 \\
GM13741 & (Leigh's) & 98 & 100 & 198 \\
GM10742 & (Leber's) & 92 & 32 & 124 \\
GM10744 & (Leber's) & 93 & 44 & 137 \\
\hline$p$-value & & 0.04 & 0.025 & 0.022 \\
\hline
\end{tabular}

The micronucleus frequencies for each dose and cell line, as determined by scoring two sets of 500 binucleated cells, were also analyzed using ANOVA. The factors evaluated were cell line (GM15510, GM15036, GM13740, GM13741, GM10742, and $\mathrm{GM} 10744)$, radiation dose $(0,1$, and $2 \mathrm{~Gy})$, and the interaction between cell line and dose. Both factors, and their interaction term, were found to be highly significant ( $p$ $<0.001$ in each case). The adjusted $r^{2}$ value was 0.98 .

Tukey HSD post hoc tests comparing the six different cell lines were then performed and the results are shown in Table 2. The dose responses observed in the 
normal and mutant cells differed significantly from each other. The dose responses for the two normal cell lines did not differ from each other. The dose responses by the Leigh's cell lines (GM13740 and GM13741), which harbor the same mutation in the ATP6 gene of respiratory chain complex V, likewise did not differ from each other. However, the dose responses observed in the two Leber's cell lines (GM10742 and GM10744) did differ significantly from each other, although they have the same mutation in the ND4 gene of respiratory chain complex I.

Table 2: Tukey HSD post hoc comparisons of the six cell lines ${ }^{\text {a }}$.

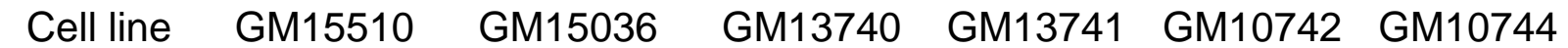
GM15510 -

\begin{tabular}{|c|c|c|c|c|c|}
\hline $\begin{array}{l}\text { GM15036 } \\
\text { (normal) }\end{array}$ & $\begin{array}{l}1.33 \\
p=0.998\end{array}$ & - & & & \\
\hline $\begin{array}{c}\text { GM13740 } \\
\text { (Leigh's) }\end{array}$ & $\begin{array}{l}47.36 \\
p<0.0001\end{array}$ & $\begin{array}{l}48.70 \\
p<0.0001\end{array}$ & - & & \\
\hline $\begin{array}{c}\text { GM13741 } \\
\text { (Leigh's) }\end{array}$ & $\begin{array}{l}15.00 \\
p=0.002\end{array}$ & $\begin{array}{l}16.33 \\
p=0.001\end{array}$ & $\begin{array}{l}32.36 \\
p<0.0001\end{array}$ & - & \\
\hline $\begin{array}{c}\text { GM10742 } \\
\text { (Leber's) }\end{array}$ & $\begin{array}{l}29.37 \\
p<0.0001\end{array}$ & $\begin{array}{l}30.70 \\
p<0.0001\end{array}$ & $\begin{array}{l}17.99 \\
p<0.0001\end{array}$ & $\begin{array}{l}14.37 \\
p=0.003\end{array}$ & - \\
\hline $\begin{array}{l}\text { GM10744 } \\
\text { (Leber's) }\end{array}$ & $\begin{array}{l}25.16 \\
p<0.0001\end{array}$ & $\begin{array}{l}26.50 \\
p<0.0001\end{array}$ & $\begin{array}{l}22.20 \\
p<0.0001\end{array}$ & $\begin{array}{l}10.16 \\
p=0.044\end{array}$ & $\begin{array}{l}4.21 \\
p=0.760\end{array}$ \\
\hline
\end{tabular}

We then performed Tukey HSD post hoc tests comparing the micronucleus frequencies for all three dose groups among all six cell lines (Table 3). As expected, there were highly significant differences in the micronucleus frequencies among the dose groups. 
Table 3: Tukey HSD post hoc comparisons of the micronucleus frequencies for all three radiation doses $^{\text {a }}$.

\begin{tabular}{cccc}
\hline $\begin{array}{l}\text { Radiation } \\
\text { Dose }\end{array}$ 0 Gy & 1 Gy & 2 Gy \\
\hline 0 Gy - & & &
\end{tabular}

\begin{tabular}{cll}
\hline 1 Gy & $\begin{array}{l}48.7 \\
p<0.0001\end{array}$ \\
& $p<0$. \\
\hline 2 Gy & 83.27 & 34.57 \\
& $p<0.0001$ & $p<0.0001$ \\
\hline a The & & - \\
\hline
\end{tabular}

a The upper number in each pair is the absolute value of the mean difference in micronucleus frequencies between the indicated cell lines; the lower number is the probability value.

$\underline{\text { Radiation-induced bystander effects in normal and mitochondrial mutant cells }}$

Bystander effects were evaluated after radiation exposure by transfer of conditioned media for each possible pair-wise combination of normal and mitochondrial mutant cell lines (Table 4). Normal cells that were grown in conditioned media obtained from the same cell line, or grown in conditioned media obtained from other normal cells, exhibited the bystander effect in every case. In contrast, mitochondrial mutant cells grown in conditioned media obtained from the same cell line or from other mitochondrial mutant cells, or grown in conditioned media obtained from normal cells, never exhibited a bystander effect. The bystander effect was also absent in normal cells grown in conditioned media obtained from mitochondrial mutant cells following radiation. In other words, the bystander effect was only observed when the "donor" and the "recipient" cell lines were both normal. If either or both of the "donor" and "recipient" cells were mutant, no bystander effect was seen. 
Table 4: Summary of results for the bystander effects evaluated in normal and mitochondrial mutant cell lines.

\begin{tabular}{|c|c|c|c|c|c|c|c|}
\hline & \multicolumn{6}{|c|}{ Recipient cells } \\
\hline & & \multicolumn{2}{|c|}{ Normal cells } & \multicolumn{4}{|c|}{ Mitochondrial mutant cells } \\
\hline & & GM15510 & GM15036 & GM13740 & GM13741 & GM10742 & GM10744 \\
\hline \multirow{6}{*}{$\begin{array}{l}\frac{\infty}{\bar{D}} \\
0 \\
\overline{0} \\
\end{array}$} & GM15510 & Yes * & Yes & No & No & No & No \\
\hline & GM15036 & Yes & Yes & No & No & No & No \\
\hline & GM13740 & No \# & No & No & No & No & No \\
\hline & GM13741 & No & No & No & No & No & No \\
\hline & GM10742 & No & No & No & No & No & No \\
\hline & GM10744 & No & No & No & No & No & No \\
\hline
\end{tabular}

${ }^{\star}$ Recipient cells exhibit a radiation-induced bystander effect.

\# Recipient cells do not exhibit a radiation-induced bystander effect.

Normal cells grown in conditioned media obtained from the same cell lines following radiation showed a dose-responsive increase in the number of micronuclei per 1000 binucleated cells (Figure 4A) indicative of the bystander effect. However, none of the four mitochondrial mutant cell lines grown in conditioned media obtained from the same cell lines following radiation showed dose-responsive increases in the number of micronuclei, thus these cells did not exhibit a bystander effect (Figure 4B). 

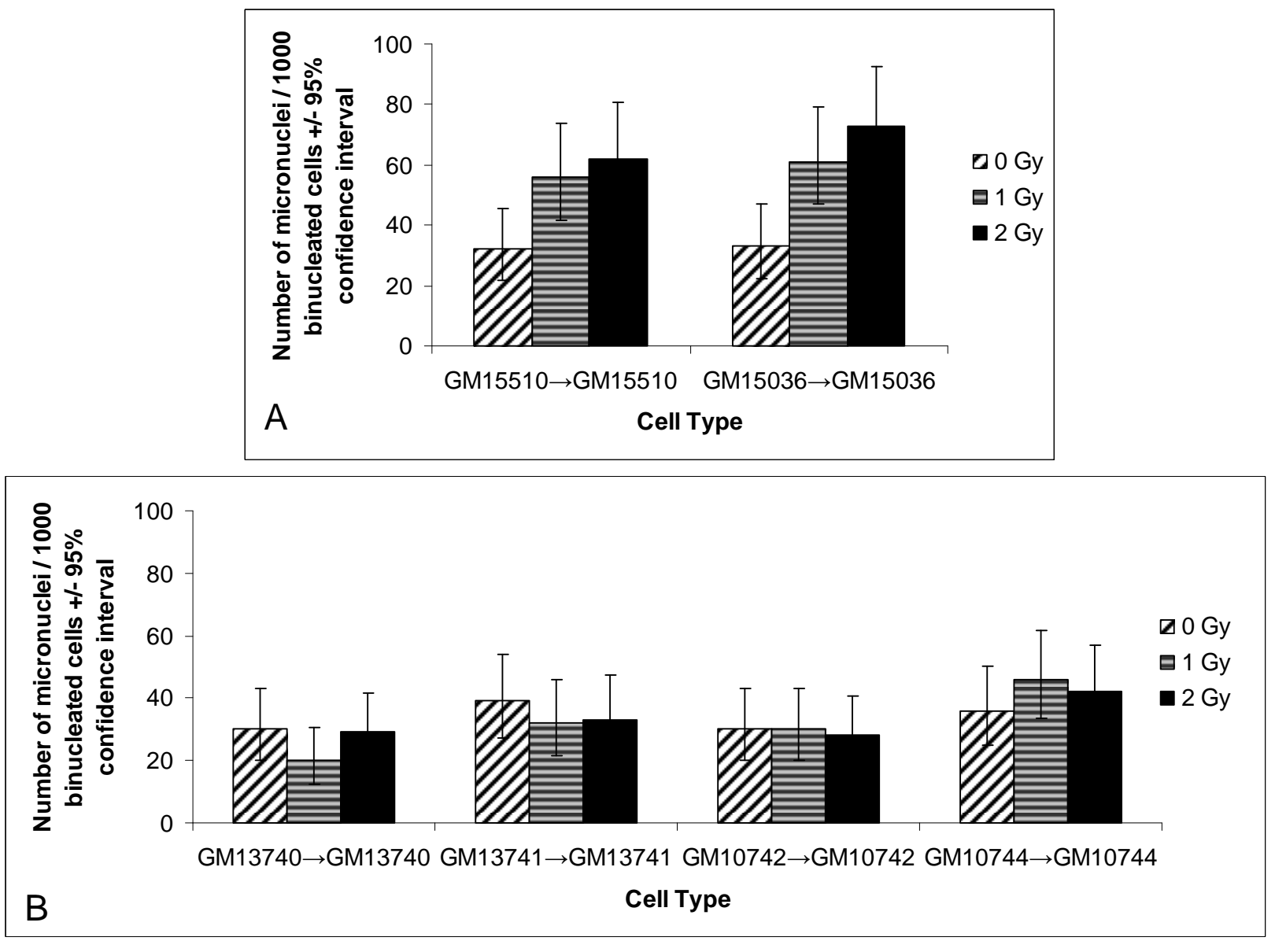

Figure 4. Micronucleus frequencies in normal and mitochondrial mutant cells grown in conditioned media obtained from the same cell line following irradiation. Normal cell lines (A) and mitochondrial mutant cell lines (B). Vertical bars represent the 95\% confidence intervals.

The normal cell lines GM15510 and GM15036 were each grown in conditioned media obtained from the other normal cell line, i.e. GM15036 and GM15510 cells, respectively. A dose-responsive increase in the number of micronuclei was observed (Figure 5A) in each case, indicating that these normal cells generate and respond to bystander signals and that these bystander signals are not cell line specific. The mitochondrial mutant cell lines were also grown in conditioned media from each of the other three mitochondrial mutant cell lines; a bystander effect was not observed under 
any of these conditions (Figures 5B, C, D and E). Among mitochondrial mutant cells exposed to conditioned media from normal cells, and vice versa, no dose-responsive increase in micronucleus frequencies was observed, and thus no radiation-induced bystander effect was evident (Figures 5F, G, H and I). Taken together, these results indicate that the mitochondrial mutant cells neither generate nor respond to bystander signals. 

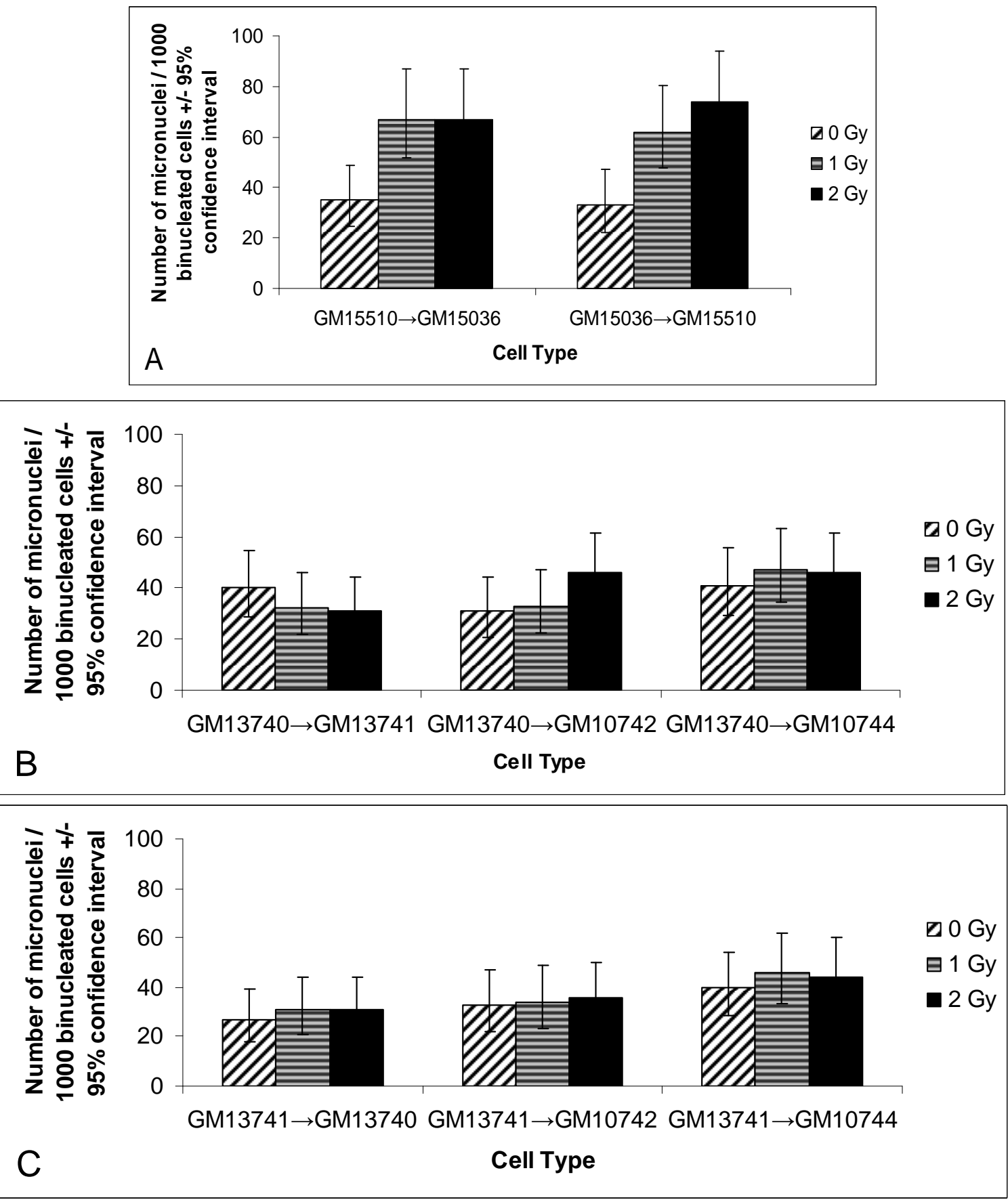

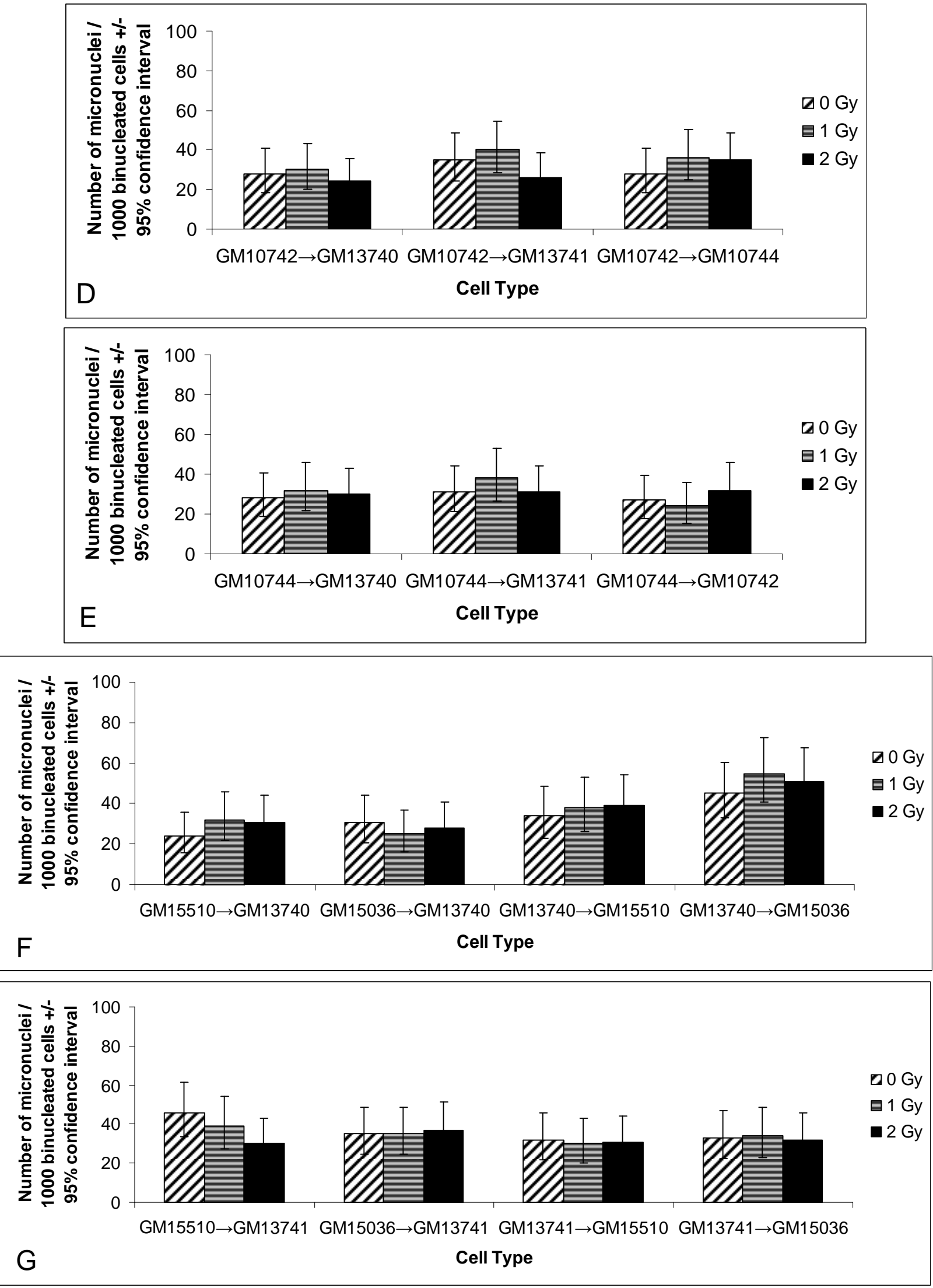

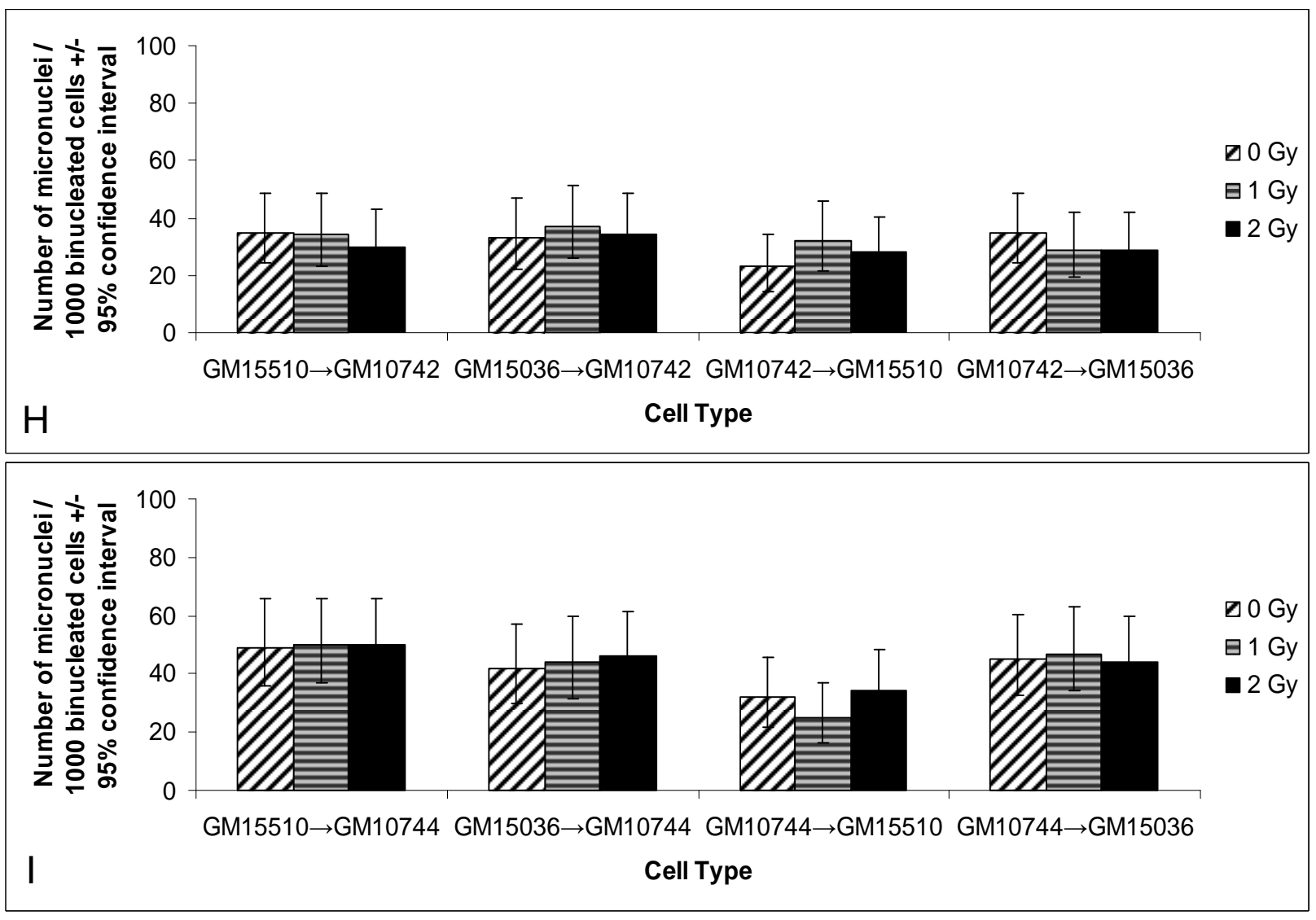

Figure 5. Micronucleus frequencies in normal and mitochondrial mutant cells grown in conditioned media obtained from other normal or mitochondrial cell lines following irradiation. (A) Normal cells grown in conditioned media obtained from other normal cells following irradiation; (B), (C), (D) and (E) mitochondrial mutant cells grown in conditioned media obtained from other mitochondrial mutant cells following irradiation; $(\mathbf{F}), \quad(\mathbf{G}), \quad(\mathbf{H})$ and $(\mathbf{I})$ normal cells grown in conditioned media obtained from mitochondrial mutant cells following irradiation and vice versa. The bystander effect was analyzed following 0 Gy (control), 1 Gy and 2 Gy. Vertical bars represent the $95 \%$ confidence intervals.

The bystander effects observed in the normal and mitochondrial mutant cell lines can readily be assigned to two distinct response groups (Figure 6). The bystander effect observed between two normal cell lines forms one group. The bystander effect observed between two mitochondrial mutant cell lines, and between normal and mitochondrial mutant cell lines, forms the second distinct group. The line is the leastsquares fit for the data in which one or both cell lines had mitochondrial mutations; the 
experiments in which both donor and the recipient cells were normal are not included in this regression. The slope is significantly greater than 0 , indicating that cultures with higher baseline (i.e. 0 dose) frequencies of micronuclei also had higher frequencies of micronuclei in the irradiated cultures.

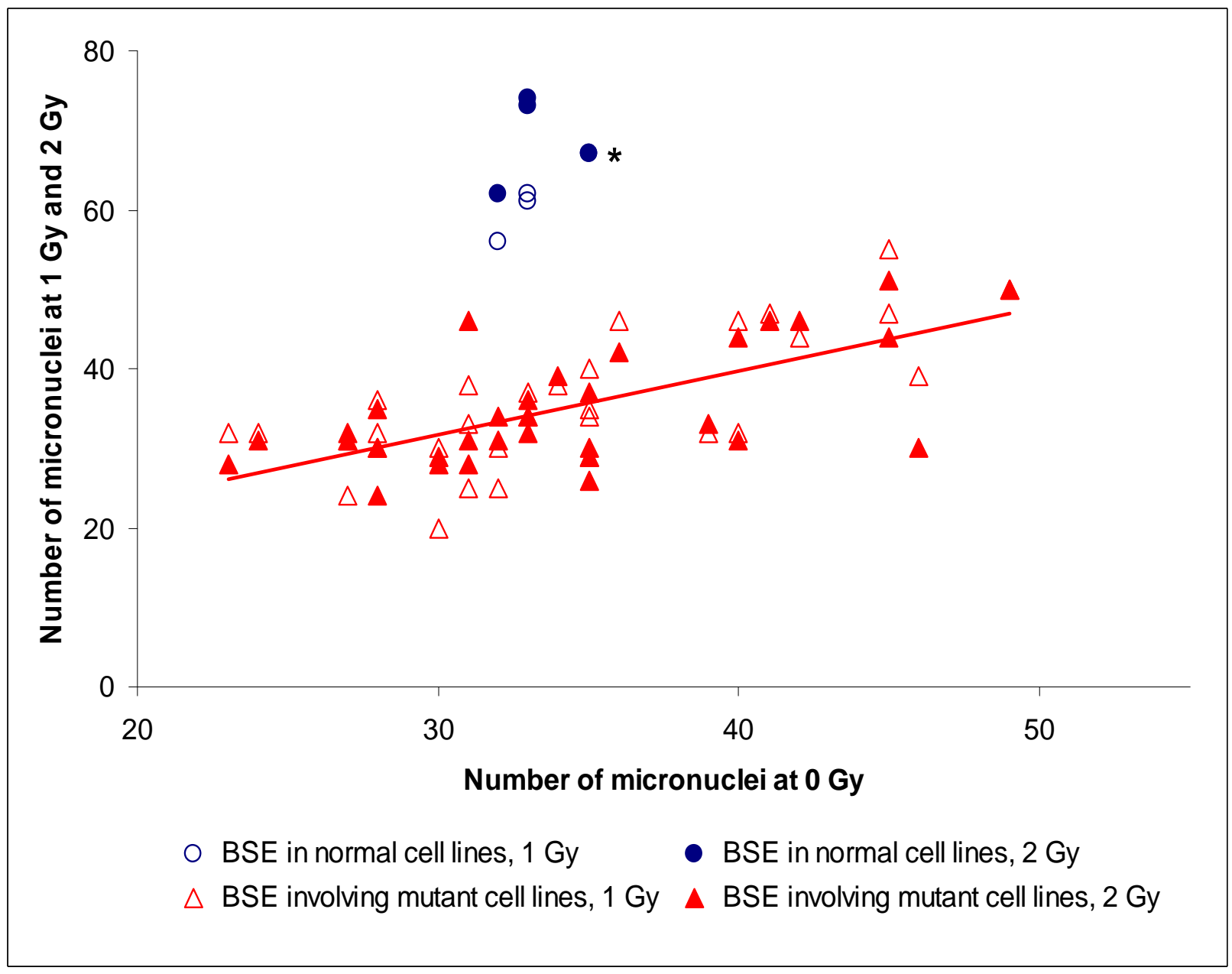

Figure 6. Bystander effects observed in normal and mitochondrial mutant cell lines. Micronucleus frequencies for normal and mitochondrial mutant cells grown in conditioned media from normal or mitochondrial mutant cells exposed to 1 Gy and 2 Gy are plotted against the micronucleus frequency at $0 \mathrm{~Gy} .{ }^{*}$ indicates two overlapping data points of the normal cell lines. BSE: bystander effect. The line is the best fit least squares regression of the data in which one or both of the cell lines had mitochondrial mutations. The equation of the line is $y=7.68+0.80 \times\left(r^{2}=0.46\right)$. The standard errors of the intercept and slope are 3.85 and 0.11 , respectively. 
To determine whether the two groups of data shown in Figure 6 were significantly different, the Welch two sample $t$-test was used. The results indicate that the two data groups differ in their micronucleus frequencies for cells grown in conditioned media obtained after 1 Gy $(p<0.0001)$ and after 2 Gy $(p=0.0002)$. The baseline micronucleus frequencies determined at 0 Gy (control) did not differ significantly between the two groups of data $(p=0.43)$. The induced micronucleus frequencies (i.e. the irradiated value minus the unirradiated value) for 1 Gy and 2 Gy were compared between the two data groups and found to differ in their induced micronucleus frequencies after 1 Gy $(p<0.0001)$ and after 2 Gy $(p=0.0003)$. This analysis of the data shown in Figure 6 clearly indicates that the bystander effect exists only when both the donor and the recipient cells do not have mitochondrial mutations, and that the bystander effect is not observed between mitochondrial mutant cells or between normal and mitochondrial mutant cells.

Determining the concentrations of mitochondrial inhibitors

To determine the optimal concentrations of mitochondrial inhibitors that led to an inhibition of bystander effect, we treated normal cells with a wide concentration range of these inhibitors and then evaluated the Nuclear Division Index (NDI) to ensure there were enough binucleated cells to enumerate micronuclei. These results are shown in Table 5 and indicate that the highest concentration of rotenone that allowed measurable numbers of binucleated cells was $10 \mathrm{nM}$ in both cell lines. The highest concentration of oligomycin that allowed measurable numbers of binucleated cells was $6 \mathrm{nM}$ in GM15510 cells and 3 nM in GM15036 cells. Higher concentrations of both compounds 
in both cell lines resulted in insufficient numbers of binucleated cells to enumerate micronuclei and analyze the inhibition of bystander effect.

Table 5: Concentration range-finding experiment for rotenone and oligomycin.

\begin{tabular}{lcccc}
\hline & \multicolumn{4}{c}{ Nuclear Division Index } \\
\cline { 2 - 5 } \multicolumn{1}{c}{ Treatment } & \multicolumn{3}{c}{ GM15036 } & \multicolumn{3}{c}{ GM15510 } \\
\cline { 2 - 5 } & $0 \mathrm{~Gy}$ & $2 \mathrm{~Gy}$ & $0 \mathrm{~Gy}$ & $2 \mathrm{~Gy}$ \\
\hline $\begin{array}{l}\text { DMSO (solvent control) } \\
\text { Rotenone (nM) }\end{array}$ & 1.31 & 1.28 & 1.41 & 1.42 \\
1.5 & 1.24 & 1.24 & 1.31 & 1.37 \\
3 & 1.26 & 1.27 & 1.28 & 1.34 \\
6 & 1.23 & 1.15 & 1.27 & 1.21 \\
10 & 1.13 & 1.19 & 1.18 & 1.20 \\
Oligomycin (nM) & & & & \\
0.75 & 1.27 & 1.29 & 1.37 & 1.39 \\
1.5 & 1.29 & 1.20 & 1.42 & 1.40 \\
3 & 1.17 & 1.12 & 1.25 & 1.25 \\
6 & 1.05 * & 1.05 * & 1.20 & 1.25 \\
\hline * Insufficient numbers of binucleated cells for the analysis \\
of micronuclei.
\end{tabular}

Determining the time period during which the bystander effect is inhibited

We then determined the window of time during which the bystander effect might be inhibited. These experiments were performed in mitochondrially normal cells, using either rotenone or oligomycin independently to evaluate inhibition of the bystander effect in cells grown in conditioned media. Inhibition of the bystander effect was analyzed by blocking the generation or the response to bystander signals, or both.

The first of these experiments was designed to determine whether inhibition of the bystander effect occurred at all. When the inhibitors were present during the entire time ("T-entire" as described in Figure 2), the micronucleus frequencies in GM15510 cells did not show a radiation dose-responsive increase when grown in conditioned 
media from the same cell line when treated with $10 \mathrm{nM}$ rotenone or with $3 \mathrm{nM}$ or $6 \mathrm{nM}$ oligomycin (Figure 7A). Similar results were seen in GM15036 cells grown in conditioned media from the same cell line when treated with $10 \mathrm{nM}$ rotenone or $3 \mathrm{nM}$ oligomycin (Figure 7B). In all other treatment conditions, including the solvent control (0.03\% DMSO) and the blank (no treatment with inhibitors or DMSO), the bystander effect was still observed. This indicates that the bystander effect is inhibited when both the generation and response to bystander signals are blocked by these inhibitors. 


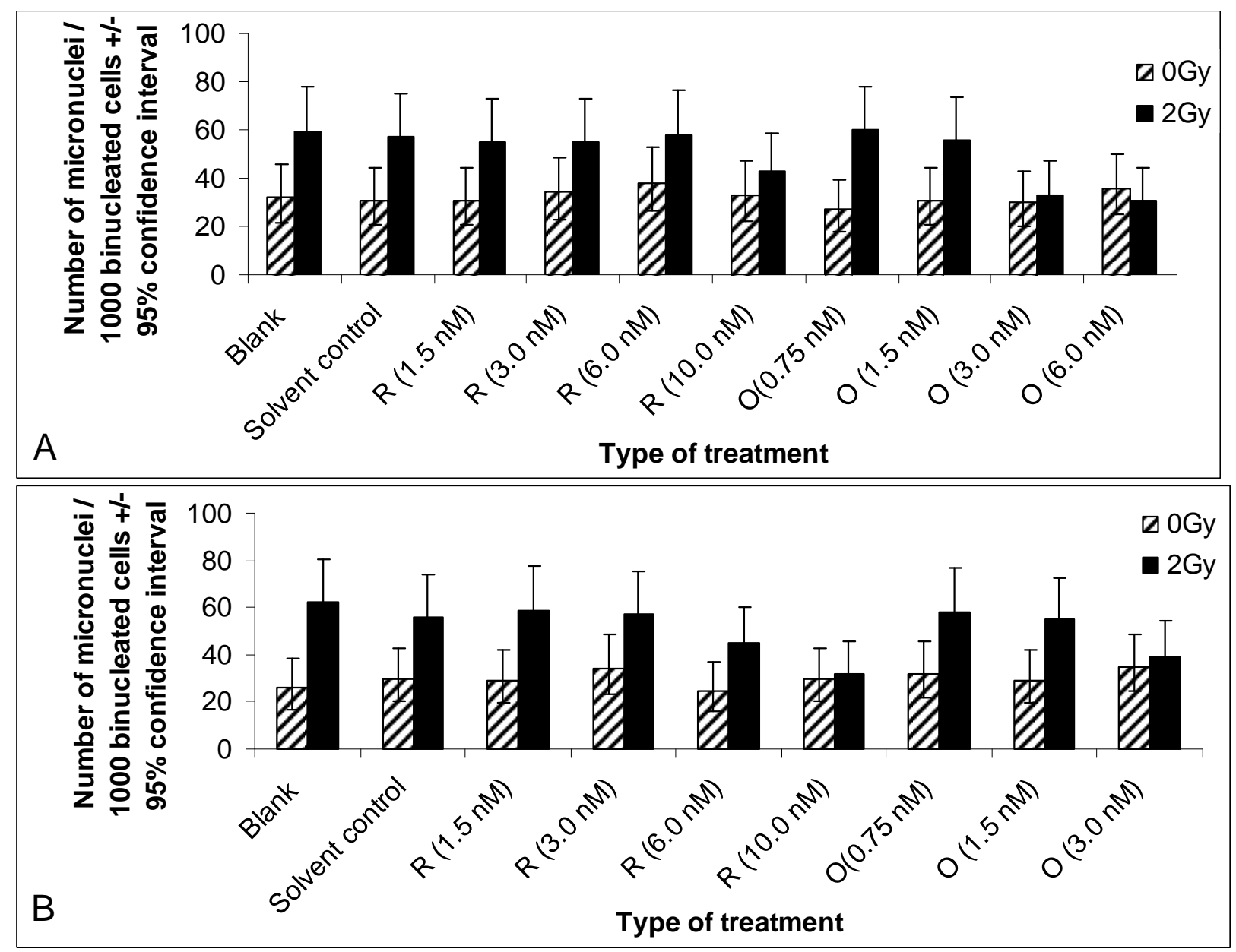

Figure 7. Micronucleus frequencies in normal cells treated with mitochondrial inhibitors during the entire culture period. Inhibition of the bystander effect in GM15510 (A) and GM15036 (B) cells treated with the indicated concentrations of rotenone or oligomycin. The bystander effect was analyzed following 0 Gy (control) and 2 Gy. Vertical bars represent the $95 \%$ confidence intervals. Blank: cells not treated with an inhibitor; solvent control: cells treated with $0.03 \%$ DMSO; R: rotenone; O: oligomycin.

The frequencies of micronuclei induced (i.e. 2 Gy minus 0 Gy) by growth in conditioned media, as determined by scoring two sets of 500 binucleated cells, were analyzed using the Welch two sample $t$-test. The results indicate that in GM15510 and GM15036 cells treated with $10 \mathrm{nM}$ rotenone, the number of micronuclei induced by the conditioned media was less than in cells treated with lower concentrations of rotenone 
$(p=0.0013)$. Similar results were observed in these same cells treated with $3 \mathrm{nM}$ oligomycin compared to cells treated with lower concentrations of oligomycin ( $p<$ 0.0001). These results indicate there is a concentration-responsive inhibition of the bystander effect in GM15510 and GM15036 cells treated with mitochondrial inhibitors that block both the generation and the response to bystander signals.

Knowing that oligomycin and rotenone were both capable of inhibiting the bystander effect, we then sought to identify a more narrow time period during which this inhibition was effective. This was accomplished with the same inhibitors in both normal cell lines. At times T1, T3 and T4 (as described in Figure 2), micronucleus frequencies in GM15510 cells did not show a radiation dose-responsive increase when grown in conditioned media from the same cell line when treated with $10 \mathrm{nM}$ rotenone or with either $3 \mathrm{nM}$ or $6 \mathrm{nM}$ oligomycin, thus indicating inhibition of the bystander effect at these three time periods (Figure 8A). Similarly, GM15036 cells showed an inhibition of the bystander effect when treated with $10 \mathrm{nM}$ rotenone or $3 \mathrm{nM}$ oligomycin at times $\mathrm{T} 1, \mathrm{~T} 3$ and T4 (Figure 8B). These results indicate that the bystander effect is inhibited when the generation or the response to bystander signals, or both, are blocked. However at time T2, the bystander effect was not inhibited for any treatment conditions in either cell line (Figures $\mathbf{8 A}$ and $\mathbf{B}$ ). The solvent control analyzed at all times exhibited the bystander effect. Taken together, these results indicate that GM15510 and GM15036 cells when treated with mitochondrial inhibitors exhibit an inhibition of bystander effect at times $\mathrm{T} 1, \mathrm{~T} 3$ and $\mathrm{T} 4$, but not at $\mathrm{T} 2$. 


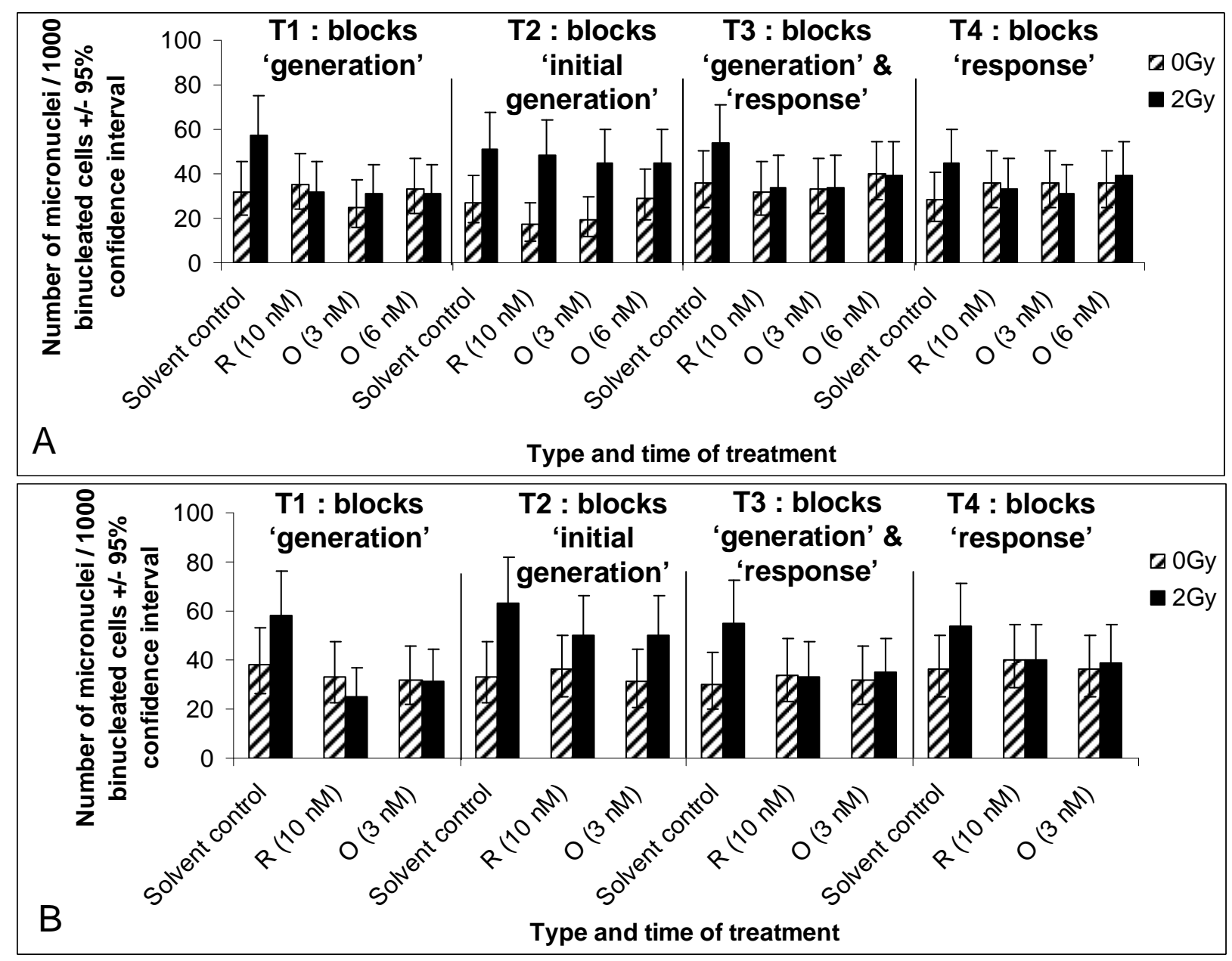

Figure 8. Micronucleus frequencies in normal cells treated with mitochondrial inhibitors at times T1, T2, T3 and T4. Inhibition of the bystander effect in GM15510 (A) and GM15036 (B) cells treated with the indicated concentrations of rotenone or oligomycin. The bystander effect was analyzed following 0 Gy (control) and 2 Gy. Vertical bars represent the $95 \%$ confidence intervals. Solvent control: cells treated with $0.03 \%$ DMSO; R: rotenone; O: oligomycin.

The mean micronucleus frequency differences between 2 Gy and 0 Gy Xirradiation data, determined by scoring two sets of 500 binucleated cells, were analyzed using ANOVA. The treatment type (DMSO, rotenone and oligomycin), treatment time (T1, T2, T3 and T4), and the interaction between treatment type and treatment time, were found to be highly significant (Table 6). The adjusted $r^{2}$ value was 0.81 . 
Table 6: ANOVA results for inhibition of the bystander effect in normal cell lines at times T1, T2, T3 and T4.

\begin{tabular}{lc}
\hline \multicolumn{1}{c}{ Source } & $p$-value \\
\hline Corrected Model & $<0.0001$ \\
Cell line & 0.40 \\
Treatment type & $<0.0001$ \\
Time & $<0.0001$ \\
Cell line * Treatment type & 0.18 \\
Cell line * Treatment time & 0.09 \\
Treatment type * Time & 0.01 \\
Cell line * Treatment type * Treatment time & 0.37 \\
\hline
\end{tabular}

Tukey HSD post hoc tests comparing the different treatment types were then performed and the results are shown in Table 7. Treatment with the solvent control DMSO differed significantly from treatments with oligomycin and rotenone. Treatment with oligomycin did not differ significantly from treatment with rotenone. These results indicate that normal cells treated with rotenone and oligomycin exhibit an inhibition of the bystander effect when compared to cells treated with the solvent control DMSO.

Table 7: Tukey HSD post hoc comparisons of the

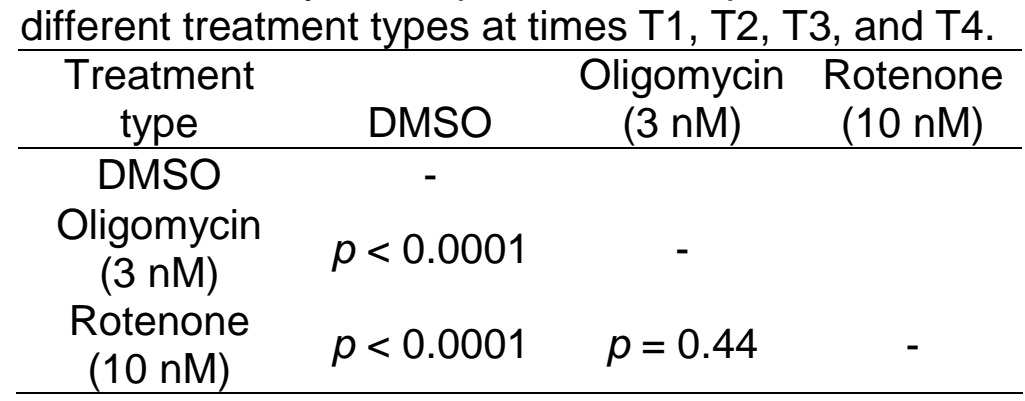

Post hoc tests comparing the different treatment times were performed and the results are shown in Table 8. Time T2 differed significantly from times T1, T3, and T4. There was no significant difference among the other three times, indicating that the inhibition occurs at times $\mathrm{T} 1, \mathrm{~T} 3$, and $\mathrm{T} 4$, but not at $\mathrm{T} 2$. 
Table 8: Tukey HSD post hoc comparisons of the treatment times T1, T2, T3, and T4.

\begin{tabular}{ccccc}
\hline $\begin{array}{c}\text { Treatment } \\
\text { time }\end{array}$ & $\mathrm{T} 1$ & $\mathrm{~T} 2$ & $\mathrm{~T} 3$ & $\mathrm{~T} 4$ \\
\hline $\mathrm{T} 1$ & - & & & \\
$\mathrm{T} 2$ & $p<0.0001$ & - & & \\
$\mathrm{T} 3$ & $p=0.92$ & $p<0.0001$ & - & \\
$\mathrm{T} 4$ & $p=0.92$ & $p<0.0001$ & $\mathrm{p}=0.58$ & - \\
\hline
\end{tabular}




\section{CHAPTER 4: Discussion}

In this study we have shown that mitochondria play an important role in the radiation-induced bystander effect by analyzing cells harboring mutations in mitochondrial genes responsible for ATP synthesis. By evaluating the generation and response to bystander signals as two individual processes, we showed that mitochondrial mutant cells do not generate or respond to bystander signals, and we showed that normal cells behave similar to the mutant cells when their mitochondrial ATP synthesis is inhibited.

Although the radiation-induced bystander effect has gained considerable interest in radiation biology, the underlying molecular mechanisms are not clear. As a consequence of cellular responses to bystander signals, the bystander effect may lead to the induction of a range of cellular processes including apoptosis, enhanced cell growth, mutations, micronuclei formation, genomic instability, and delayed cell death (Mothersill \& Seymour, 1997, Lorimore et al., 1998, Wu et al., 1999, Seymour \& Mothersill, 1997). Early genomic instability such as telomere shortening and bridge formation coupled with mitochondrial dysfunction is reported (Gorman et al., 2009). Calcium signaling, mitochondria and the hexose monophosphate shunt are involved in apoptosis, and exposing unirradiated cells to medium from irradiated cells resulted in a calcium signal within minutes (Lyng et al., 2000). While the bystander effect leads to a number of deleterious responses as described above, including chromosomal aberrations, sister chromatid exchanges and gene mutations (Hamada, 2009, Nagasawa et al., 2005, Schmid \& Roos, 2009), it also leads to a protective adaptive response (Martin et al., 2009, Zhang et al., 2009). Cells exposed to bystander signals 
become more resistant to subsequent irradiations than cells that are not exposed to bystander signals. This is because of the protective adaptive response induced by the bystander signals. Bystander cells show increased rates of cell proliferation (lyer et al., 2000) and release of growth inhibitory factors (Komarova et al., 1998). Thus, the bystander effect can be both deleterious and advantageous to the cells. Hence, it is important to understand the molecular mechanisms that underlie the bystander effect.

Understanding the molecular mechanisms of the bystander effect is important as the various factors involved in the bystander pathway(s) and the targets for radiation therapy and risk assessment may be determined. Future radiation therapy strategies may be enhanced by improving our understanding of differential DNA damage responses in cells that are directly versus indirectly exposed (Prise \& O'Sullivan, 2009). Strategies to maximize the bystander responses in tumor cells and minimize their effects in normal cells could be also formulated (Prise \& O'Sullivan, 2009). This will help the development of better radio-protective agents and better radiation therapies while decreasing the risk to patients of undesired side effects of radiotherapy.

ATP serves as an important energy source in a number of cellular processes including repair and apoptosis. In the past decade, several studies have shown that mitochondria play an important role in radiation-induced cellular responses including apoptosis, changes in membrane potential, and increased ROS production. In cells directly irradiated there is depolarization of mitochondrial membrane potential, release of cytochrome $\mathrm{c}$ and an increase in ROS production that induces mitochondrial damage (Leach et al., 2001). In cells that are subjected to medium from irradiated cells there are changes including loss of mitochondrial membrane potential, an increase in ROS and 
an increase in apoptosis in receptor cells (Lyng et al., 2000). ROS plays a role in perpetuating the bystander effect (Lyng et al., 2002, lyer et al., 2000). Mitochondriadependent intercellular signaling from irradiated cells up-regulates ROS that mediates genotoxicity of bystander effects (Chen et al., 2009). An increase in ROS has been associated with an increase in mitochondrial mass to compensate for the reduced mitochondrial function (Limoli et al., 2003, Lee et al., 2005, Nugent et al., 2007). Mitochondria-derived nitric oxide and oxygen free radicals play a role in the initiation and activation of the early process of radiation-induced bystander effect (Chen et al., 2008). Cells lacking mitochondrial DNA are less efficient in generating bystander signals (Zhou et al., 2008, Tartier et al., 2007) and the bystander effect is known to be an energy dependent process (Mothersill et al., 2000). Based on these studies, we hypothesized that mitochondrial mutant cell lines deficient in ATP synthesis will exhibit a decreased bystander effect.

The bystander effect can occur either via gap-junction mediated cell-to-cell contact or through soluble transmissible factors secreted into the media. In the present study, the normal and mitochondrial mutant cell lines used do not exhibit cell-to-cell contacts and thus, any bystander effect observed would be due only to soluble transmissible factors secreted into the media. The normal cell lines used are known to exhibit the bystander effect and were employed as controls. The mitochondrial mutant cell lines harbor point mutations in the ND4 gene of complex I or in the ATP6 gene of complex $V$ that lead to Leber's optic atrophy and Leigh's syndrome, respectively. People with these mutations show severe deficiency in ATP synthesis (Majander et al., 1996, Dahl, 1998). 
Before analyzing the radiation-induced bystander effect in these cell lines, we first characterized these cells' response to ionizing radiation. Both the normal and all four of the mitochondrial mutant cell lines showed dose-responsive increases in micronucleus frequencies when they were directly exposed to radiation. The normal cells showed a significantly greater dose response than the mutant cells. We then analyzed the radiation-induced bystander effect in all six cell lines. The results show that the cells harboring mutations in mitochondrial genes responsible for ATP synthesis do not exhibit the bystander effect while the normal cells do; implicating the bystander effect to be energy-dependent (Mothersill et al., 2000).

It is important to determine whether the absence of a bystander effect in mitochondrial mutant cells is due to impairment of the generation or of the response to bystander signals, or both. To study the generation and response to bystander signals as two individual processes, mitochondrial mutant cells were grown in conditioned media from normal cells following radiation exposure and vice versa. Because conditioned media is transferred to or from the normal cell lines, which can both generate and respond to bystander signals, the absence of a bystander effect determines whether the mitochondrial mutant cells are deficient in the generation or in the response to bystander signals, or both. If there is no bystander effect in mutant cells grown in conditioned media obtained from normal cells following radiation, it indicates that the mutant cells cannot respond to bystander signals, as it is known that the normal cells generate bystander signals. If there is no bystander effect in normal cells grown in conditioned media from mutant cells following radiation, it indicates that the mutant cells 
cannot generate bystander signals, as it is known that the normal cells respond to bystander signals.

In our experiments, there was no bystander effect in normal cells grown in conditioned media obtained from mutant cells following radiation and vice versa. This clearly indicates that the cells harboring mutations in mitochondrial genes responsible for ATP synthesis neither generate nor respond to bystander signals. The generation of bystander signals is energy-dependent (Mothersill et al., 2000). A recent study with cells lacking cytochrome c, which plays a crucial role in ATP synthesis, shows that these cells do not respond to bystander signals (Yang et al., 2009). Thus, mitochondrial ATP synthesis appears to play an essential role in both the generation and response to bystander signals.

To further illustrate the importance of mitochondria in the radiation-induced bystander effect, we analyzed the bystander effect in normal cells after the inhibition of their mitochondrial complexes responsible for ATP synthesis. The mutant cells used in this study harbor mutations in complex I and complex $V$ of the respiratory chain, both of which are involved in ATP synthesis. Thus, the normal cells were treated with the mitochondrial inhibitors, rotenone and oligomycin, that are known to inhibit complexes I and $\mathrm{V}$, respectively.

To determine if treatment with these inhibitors led to an inhibition of bystander effect at all, we first analyzed the bystander effect in normal cells treated with different concentrations of rotenone and oligomycin at time T-entire. The cells were treated with the inhibitors during the entire culture period, blocking both the generation and response to bystander signals. The results indicate that GM15036 cells treated with $10 \mathrm{nM}$ 
rotenone and $3 \mathrm{nM}$ oligomycin do not exhibit the bystander effect. Similar results were seen in GM15510 cells treated with $10 \mathrm{nM}$ rotenone and, 3 and $6 \mathrm{nM}$ oligomycin. Thus, the bystander effect is inhibited when both the generation and response to bystander signals are blocked.

Having determined the concentrations of inhibitors that led to an inhibition of bystander effect, we were then interested in determining the time during which the inhibition was effective. The bystander effect was analyzed in normal cells treated with the inhibitors at different times before, during and after radiation. At time $\mathrm{T} 1$, when the inhibitors were added 24 hours before radiation and were removed immediately after radiation, the generation of bystander signals might be blocked. At time T3, the generation and response to bystander signals might be blocked, as the inhibitors were added immediately after radiation and were not removed until the end of the experiment. At time T4, when the inhibitors were added immediately after exposing the cells to the conditioned media from the same cell line following radiation, the response to bystander signals might be blocked. At all these three inhibition times, when the generation or the response to bystander signals, or both were blocked, we hypothesized to see an inhibition of bystander effect. The results indicate that there is no bystander effect at all these three inhibition times. This follows our hypothesis that the bystander effect is inhibited when the generation or the response to bystander signals, or both are blocked. At time T2, the inhibitors were added just prior to radiation and were removed immediately after radiation. This might block the initial generation of bystander signals. However, there is no inhibition of bystander effect at this time. This might be because at this time, the cells were treated with the inhibitors for only a short period of time unlike 
the other times where the cells were treated with the inhibitors for at least 24 hours, and this short time of treatment might not be sufficient to cause the inhibition.

In summary, this study clearly indicates that the cells harboring mutations in mitochondrial genes and, also the normal cells in which the mitochondrial ATP synthesis is inhibited do not exhibit the bystander effect. This concludes that the mitochondrial ATP synthesis in human lymphoblastoid cells plays an important role in the generation and response to bystander signals and thus, the bystander effect. 


\section{CHAPTER 5: Future Directions}

In this study we have shown that mitochondria play an important mechanistic role in both the generation and response to bystander signals. However, the molecular pathways involved in the bystander effect and the specific role of mitochondria in these pathways remain to be elucidated. We have analyzed the radiation-induced bystander effect in mitochondrial mutant cell lines that harbor mutations in the ND4 gene and in the ATP6 gene of mitochondrial electron transport chain complexes I and V, respectively. Additional cell lines that harbor a broader range of mitochondrial mutations should be analyzed to further elucidate the bystander mechanisms. Our results suggest that patients suffering from Leber's optic atrophy or Leigh's syndrome, in which the mitochondrial mutations lead to decreased ATP synthesis, are not at risk for radiationinduced bystander effects. Nevertheless, it is quite possible that these patients do have altered radiobiological risks. While we have shown that mitochondria play an essential role in the radiation-induced bystander effect, the role of mitochondria in bystander effects caused by other genotoxic agents such as chemicals and photodynamic stress remains to be determined. 


\section{REFERENCES}

Alexeyev, M. F., Ledoux, S. P. \& Wilson, G. L. (2004) Mitochondrial DNA and aging. Clin Sci (Lond), 107, 355-364.

Andersson, S. G., Karlberg, O., Canback, B. \& Kurland, C. G. (2003) On the origin of mitochondria: a genomics perspective. Philos Trans R Soc Lond B Biol Sci, 358, 165-177; discussion 177-169.

Asur, R., Balasubramaniam, M., Marples, B., Thomas, R. A. \& Tucker, J. D. (2009a) Involvement of MAPK proteins in bystander effects induced by chemicals and ionizing radiation. Mutat Res.

Asur, R. S., Thomas, R. A. \& Tucker, J. D. (2009b) Chemical induction of the bystander effect in normal human lymphoblastoid cells. Mutat Res, 676, 11-16.

Azzam, E. I., de Toledo, S. M., Gooding, T. \& Little, J. B. (1998) Intercellular communication is involved in the bystander regulation of gene expression in human cells exposed to very low fluences of alpha particles. Radiat Res, 150, 497-504.

Azzam, E. I., de Toledo, S. M., Waker, A. J. \& Little, J. B. (2000) High and low fluences of alpha-particles induce a G1 checkpoint in human diploid fibroblasts. Cancer Res, 60, 2623-2631.

Banerjee, G., Gupta, N., Kapoor, A. \& Raman, G. (2005) UV induced bystander signaling leading to apoptosis. Cancer Lett, 223, 275-284.

Brown, M. D., Voljavec, A. S., Lott, M. T., MacDonald, I. \& Wallace, D. C. (1992) Leber's hereditary optic neuropathy: a model for mitochondrial neurodegenerative diseases. FASEB J, 6, 2791-2799. 
Bykhovskaya, Y., Mengesha, E., Wang, D., Yang, H., Estivill, X., Shohat, M. \& FischelGhodsian, N. (2004) Human mitochondrial transcription factor B1 as a modifier gene for hearing loss associated with the mitochondrial A1555G mutation. Mol Genet Metab, 82, 27-32.

Cahill, D., Connor, B. \& Carney, J. P. (2006) Mechanisms of eukaryotic DNA double strand break repair. Front Biosci, 11, 1958-1976.

Cavalier-Smith, T. (2006) Origin of mitochondria by intracellular enslavement of a photosynthetic purple bacterium. Proc Biol Sci, 273, 1943-1952.

Chakraborty, A., Held, K. D., Prise, K. M., Liber, H. L. \& Redmond, R. W. (2009) Bystander effects induced by diffusing mediators after photodynamic stress. Radiat Res, 172, 74-81.

Chen, S., Zhao, Y., Han, W., Zhao, G., Zhu, L., Wang, J., Bao, L., Jiang, E., Xu, A., Hei, T. K., Yu, Z. \& Wu, L. (2008) Mitochondria-dependent signalling pathway are involved in the early process of radiation-induced bystander effects. $\mathrm{Br} J$ Cancer, 98, $1839-1844$.

Chen, S., Zhao, Y., Zhao, G., Han, W., Bao, L., Yu, K. N. \& Wu, L. (2009) Up-regulation of ROS by mitochondria-dependent bystander signaling contributes to genotoxicity of bystander effects. Mutat Res, 666, 68-73.

Dahl, H. H. (1998) Getting to the nucleus of mitochondrial disorders: identification of respiratory chain-enzyme genes causing Leigh syndrome. Am J Hum Genet, 63, 1594-1597. 
DeHaan, C., Habibi-Nazhad, B., Yan, E., Salloum, N., Parliament, M. \& Allalunis-Turner, J. (2004) Mutation in mitochondrial complex I ND6 subunit is associated with defective response to hypoxia in human glioma cells. Mol Cancer, 3, 19.

Dent, P., Yacoub, A., Fisher, P. B., Hagan, M. P. \& Grant, S. (2003) MAPK pathways in radiation responses. Oncogene, 22, 5885-5896.

Eastmond, D. A. \& Tucker, J. D. (1989) Identification of aneuploidy-inducing agents using cytokinesis-blocked human lymphocytes and an antikinetochore antibody. Environ Mol Mutagen, 13, 34-43.

Elmore, S. (2007) Apoptosis: a review of programmed cell death. Toxicol Pathol, 35, 495-516.

Emerit, I. (1994) Reactive oxygen species, chromosome mutation, and cancer: possible role of clastogenic factors in carcinogenesis. Free Radic Biol Med, 16, 99-109.

Faguet, G. B., Reichard, S. M. \& Welter, D. A. (1984) Radiation-induced clastogenic plasma factors. Cancer Genet Cytogenet, 12, 73-83.

Fenech, M. \& Morley, A. A. (1985) Measurement of micronuclei in lymphocytes. Mutat Res, 147, 29-36.

Fiskum, G., Murphy, A. N. \& Beal, M. F. (1999) Mitochondria in neurodegeneration: acute ischemia and chronic neurodegenerative diseases. J Cereb Blood Flow Metab, 19, 351-369.

Gorman, S., Tosetto, M., Lyng, F., Howe, O., Sheahan, K., O'Donoghue, D., Hyland, J., Mulcahy, H. \& O'Sullivan, J. (2009) Radiation and chemotherapy bystander effects induce early genomic instability events: telomere shortening and bridge formation coupled with mitochondrial dysfunction. Mutat Res, 669, 131-138. 
Goyanes-Villaescusa, V. (1971) Chromosomal abnormalities in lymphocytes of children and baby rabbits born from mothers treated by $\mathrm{x}$-radiation before pregnancy. A transplacentary plasmatic chromosome-damaged factor? Blut, 22, 93-96.

Hamada, N. (2009) Recent insights into the biological action of heavy-ion radiation. $J$ Radiat Res (Tokyo), 50, 1-9.

Hollowell, J. G., Jr. \& Littlefield, L. G. (1968) Chromosome damage induced by plasma of x-rayed patients: an indirect effect of x-ray. Proc Soc Exp Biol Med, 129, 240244.

lyer, R., Lehnert, B. E. \& Svensson, R. (2000) Factors underlying the cell growth-related bystander responses to alpha particles. Cancer Res, 60, 1290-1298.

Kashino, G., Prise, K. M., Schettino, G., Folkard, M., Vojnovic, B., Michael, B. D., Suzuki, K., Kodama, S. \& Watanabe, M. (2004) Evidence for induction of DNA double strand breaks in the bystander response to targeted soft X-rays in $\mathrm{CHO}$ cells. Mutat Res, 556, 209-215.

Kashino, G., Suzuki, K., Matsuda, N., Kodama, S., Ono, K., Watanabe, M. \& Prise, K. M. (2007) Radiation induced bystander signals are independent of DNA damage and DNA repair capacity of the irradiated cells. Mutat Res, 619, 134-138.

Komarova, E. A., Diatchenko, L., Rokhlin, O. W., Hill, J. E., Wang, Z. J., Krivokrysenko, V. I., Feinstein, E. \& Gudkov, A. V. (1998) Stress-induced secretion of growth inhibitors: a novel tumor suppressor function of p53. Oncogene, 17, 1089-1096.

Leach, J. K., Van Tuyle, G., Lin, P. S., Schmidt-Ullrich, R. \& Mikkelsen, R. B. (2001) Ionizing radiation-induced, mitochondria-dependent generation of reactive oxygen/nitrogen. Cancer Res, 61, 3894-3901. 
Lee, C. F., Liu, C. Y., Hsieh, R. H. \& Wei, Y. H. (2005) Oxidative stress-induced depolymerization of microtubules and alteration of mitochondrial mass in human cells. Ann N Y Acad Sci, 1042, 246-254.

Lilienfeld, A., Pedersen, E. \& Dowd, J. (1967) Cancer Epidemiology: Methods of Study. The Johns Hopkins University Press, Baltimore.

Limoli, C. L., Giedzinski, E., Morgan, W. F., Swarts, S. G., Jones, G. D. \& Hyun, W. (2003) Persistent oxidative stress in chromosomally unstable cells. Cancer Res, 63, 3107-3111.

Lorimore, S. A., Kadhim, M. A., Pocock, D. A., Papworth, D., Stevens, D. L., Goodhead, D. T. \& Wright, E. G. (1998) Chromosomal instability in the descendants of unirradiated surviving cells after alpha-particle irradiation. Proc Natl Acad Sci U S A, 95, 5730-5733.

Lyng, F. M., Seymour, C. B. \& Mothersill, C. (2000) Production of a signal by irradiated cells which leads to a response in unirradiated cells characteristic of initiation of apoptosis. Br J Cancer, 83, 1223-1230.

Lyng, F. M., Seymour, C. B. \& Mothersill, C. (2002) Initiation of apoptosis in cells exposed to medium from the progeny of irradiated cells: a possible mechanism for bystander-induced genomic instability? Radiat Res, 157, 365-370.

Maguire, P., Mothersill, C., Seymour, C. \& Lyng, F. M. (2005) Medium from irradiated cells induces dose-dependent mitochondrial changes and BCL2 responses in unirradiated human keratinocytes. Radiat Res, 163, 384-390.

Majander, A., Finel, M., Savontaus, M. L., Nikoskelainen, E. \& Wikstrom, M. (1996) Catalytic activity of complex I in cell lines that possess replacement mutations in 
the ND genes in Leber's hereditary optic neuropathy. Eur J Biochem, 239, 201207.

Martin, C. J., Sutton, D. G., West, C. M. \& Wright, E. G. (2009) The radiobiology/radiation protection interface in healthcare. J Radiol Prot, 29, A1A20.

Morel, F., Debise, R., Renoux, M., Touraille, S., Ragno, M. \& Alziari, S. (1999) Biochemical and molecular consequences of ethidium bromide treatment on Drosophila cells. Insect Biochem Mol Biol, 29, 835-843.

Mothersill, C., Rea, D., Wright, E. G., Lorimore, S. A., Murphy, D., Seymour, C. B. \& O'Malley, K. (2001) Individual variation in the production of a 'bystander signal' following irradiation of primary cultures of normal human urothelium. Carcinogenesis, 22, 1465-1471.

Mothersill, C. \& Seymour, C. (1997) Medium from irradiated human epithelial cells but not human fibroblasts reduces the clonogenic survival of unirradiated cells. Int $J$ Radiat Biol, 71, 421-427.

Mothersill, C. \& Seymour, C. (2001) Radiation-induced bystander effects: past history and future directions. Radiat Res, 155, 759-767.

Mothersill, C. \& Seymour, C. (2003) Radiation-induced bystander effects, carcinogenesis and models. Oncogene, 22, 7028-7033.

Mothersill, C. \& Seymour, C. B. (1998) Cell-cell contact during gamma irradiation is not required to induce a bystander effect in normal human keratinocytes: evidence for release during irradiation of a signal controlling survival into the medium. Radiat Res, 149, 256-262. 
Mothersill, C. \& Seymour, C. B. (2004) Radiation-induced bystander effects-implications for cancer. Nat Rev Cancer, 4, 158-164.

Mothersill, C., Stamato, T. D., Perez, M. L., Cummins, R., Mooney, R. \& Seymour, C. B. (2000) Involvement of energy metabolism in the production of 'bystander effects' by radiation. $\mathrm{Br} \mathrm{J}$ Cancer, 82, 1740-1746.

Nagasawa, H., Peng, Y., Wilson, P. F., Lio, Y. C., Chen, D. J., Bedford, J. S. \& Little, J. B. (2005) Role of homologous recombination in the alpha-particle-induced bystander effect for sister chromatid exchanges and chromosomal aberrations. Radiat Res, 164, 141-147.

Nugent, S. M., Mothersill, C. E., Seymour, C., McClean, B., Lyng, F. M. \& Murphy, J. E. (2007) Increased mitochondrial mass in cells with functionally compromised mitochondria after exposure to both direct gamma radiation and bystander factors. Radiat Res, 168, 134-142.

Pant, G. S. \& Kamada, N. (1977) Chromosome aberrations in normal leukocytes induced by the plasma of exposed individuals. Hiroshima J Med Sci, 26, 149154.

Parsons, W. B., Jr., Watkins, C. H., Pease, G. L. \& Childs, D. S., Jr. (1954) Changes in sternal marrow following roentgen-ray therapy to the spleen in chronic granulocytic leukemia. Cancer, 7, 179-189.

Prise, K. M. \& O'Sullivan, J. M. (2009) Radiation-induced bystander signalling in cancer therapy. Nat Rev Cancer, 9, 351-360. 
Rufa, A., Dotti, M. T., Cardaioli, E., Da Pozzo, P. \& Federico, A. (2005) Leber hereditary optic neuropathy in 2 of 4 siblings with 11778 mtDNA mutation: clinical variability or effect of toxic environmental exposure? Eur Neurol, 53, 32-34.

Schmid, E. \& Roos, H. (2009) Influence of the bystander phenomenon on the chromosome aberration pattern in human lymphocytes induced by in vitro alphaparticle exposure. Radiat Environ Biophys, 48, 181-187.

Seymour, C. B. \& Mothersill, C. (1997) Delayed expression of lethal mutations and genomic instability in the progeny of human epithelial cells that survived in a bystander-killing environment. Radiat Oncol Investig, 5, 106-110.

Sugahara, T. \& Watanabe, M. (1994) Epigenetic nature of radiation carcinogenesis at low doses. Chin Med J (Engl), 107, 405-410.

Sun, F., Ashley-Koch, A. E., Durham, L. K., Feingold, E., Halloran, M. E., Manatunga, A. K. \& Sherman, S. L. (1998) Testing for contributions of mitochondrial DNA mutations to complex diseases. Genet Epidemiol, 15, 451-469.

Tartier, L., Gilchrist, S., Burdak-Rothkamm, S., Folkard, M. \& Prise, K. M. (2007) Cytoplasmic irradiation induces mitochondrial-dependent 53BP1 protein relocalization in irradiated and bystander cells. Cancer Res, 67, 5872-5879.

Vines, A. M., Lyng, F. M., McClean, B., Seymour, C. \& Mothersill, C. E. (2008) Bystander signal production and response are independent processes which are cell line dependent. Int J Radiat Biol, 84, 83-90.

Wu, L. J., Randers-Pehrson, G., Xu, A., Waldren, C. A., Geard, C. R., Yu, Z. \& Hei, T. K. (1999) Targeted cytoplasmic irradiation with alpha particles induces mutations in mammalian cells. Proc Natl Acad Sci U S A, 96, 4959-4964. 
Yang, G., Wu, L., Chen, S., Zhu, L., Huang, P., Tong, L., Zhao, Y., Zhao, G., Wang, J., Mei, T., Xu, A. \& Wang, Y. (2009) Mitochondrial dysfunction resulting from loss of cytochrome c impairs radiation-induced bystander effect. Br J Cancer, 100, 19121916.

Zhang, Y., Zhou, J., Baldwin, J., Held, K. D., Prise, K. M., Redmond, R. W. \& Liber, H. L. (2009) lonizing radiation-induced bystander mutagenesis and adaptation: quantitative and temporal aspects. Mutat Res, 671, 20-25.

Zhou, H., Ivanov, V. N., Lien, Y. C., Davidson, M. \& Hei, T. K. (2008) Mitochondrial function and nuclear factor-kappaB-mediated signaling in radiation-induced bystander effects. Cancer Res, 68, 2233-2240. 


\section{ABSTRACT}

\section{THE ROLE OF MITOCHONDRIA IN THE RADIATION-INDUCED BYSTANDER EFFECT IN HUMAN LYMPHOBLASTOID CELLS}

by

\section{SOUNTHARIA RAJENDRAN}

\section{May 2010}

Advisor: Dr. James D. Tucker

Major: Biological Sciences

Degree: $\quad$ Master of Science

This work evaluated the radiation-induced bystander effect in mitochondrial mutant cells and in normal cells treated with mitochondrial inhibitors. Although much research has been performed on the bystander effect, the underlying molecular mechanisms remain largely unknown. Cells without intact mitochondrial DNA have been shown to lack the bystander effect, which is an energy-dependent process. Based on these findings, cells harboring mutations in the mitochondrial genes responsible for ATP synthesis, and normal cells treated with mitochondrial inhibitors, were hypothesized to show a decreased bystander effect when compared to normal cells that were not treated with the mitochondrial inhibitors.

Radiation-induced bystander effects were analyzed in normal and mitochondrial mutant human lymphoblastoid cells using the cytokinesis block micronucleus assay. The results indicate that the mitochondrial mutant cells do not exhibit the bystander effect while the normal cells do. Both the normal and mitochondrial mutant cells were found to show a dose-responsive increase in DNA damage upon direct exposure to radiation. 
The generation of and response to bystander signals in the normal and mitochondrial mutant cells were then analyzed by evaluating the radiation-induced bystander effects between each possible pair-wise combination of normal and mutant cell lines. Normal cells were found to generate and to respond to bystander signals, while the mitochondrial mutant cells neither generated nor responded to bystander signals.

To determine whether normal cells behave similar to the mutant cells when their mitochondrial ATP synthesis is inhibited, the radiation-induced bystander effect in normal cells treated with mitochondrial inhibitors was evaluated. The results indicate that the normal cells treated with rotenone or oligomycin do not exhibit the bystander effect. To determine the time period during which the inhibition was effective, normal cells were treated with the inhibitors at different times before, during and after radiation. The results indicate that normal cells do not exhibit the bystander effect when the inhibitors were added 24 hours before radiation and were removed immediately after radiation. Similarly, normal cells treated with the inhibitors after radiation did not exhibit the bystander effect. However, when the inhibitors were added just prior to radiation and were removed immediately after radiation, normal cells did not show an inhibition of bystander effect, indicating that this short period of treatment might not be sufficient to cause the inhibition.

These results indicate that mitochondrial ATP synthesis in human lymphoblastoid cells plays an important role in the generation and response to bystander signals and thus, the bystander effect. 


\section{AUTOBIOGRAPHICAL STATEMENT SOUNTHARIA RAJENDRAN}

\section{EDUCATION:}

2007-2010 M.S. in Biological Sciences, Wayne State University, Detroit, Michigan, USA

2002-2006 M.Sc. (Hons.) in Biological Sciences, Birla Institute of Technology and Science, Pilani, Rajasthan, India

\section{EMPLOYMENT:}

2006-2007 Programmer Analyst, Cognizant Technology Solutions India Pvt. Ltd., Chennai, Tamil Nadu, India

\section{AWARDS:}

2009 Graduate Teaching Assistant award 